\title{
Accounting Standards and International Portfolio Holdings
}

\section{Citation}

Yu, Gwen, and Aida Sijamic Wahid. "Accounting Standards and International Portfolio Holdings." Accounting Review 89, no. 5 (September 2014): 1895-1930.

\section{Published Version}

http://aaapubs.org/doi/abs/10.2308/accr-50801

\section{Permanent link}

http://nrs.harvard.edu/urn-3:HUL.InstRepos:17416810

\section{Terms of Use}

This article was downloaded from Harvard University's DASH repository, and is made available under the terms and conditions applicable to Open Access Policy Articles, as set forth at http:// nrs.harvard.edu/urn-3:HUL.InstRepos:dash.current.terms-of-use\#OAP

\section{Share Your Story}

The Harvard community has made this article openly available.

Please share how this access benefits you. Submit a story.

Accessibility 


\title{
Accounting Standards and International Portfolio Holdings
}

\author{
by \\ Gwen $\mathrm{Yu}^{1}$ \\ Aida Sijamic Wahid ${ }^{2}$ \\ [Conditionally accepted at The Accounting Review]
}

\begin{abstract}
Do differences in countries' accounting standards affect global investment decisions? We explore this question by examining how accounting distance, the difference in the accounting standards used in the investor's and the investee's countries, affects the asset allocation decisions of global mutual funds. We find that investors tend to underweight investees with greater accounting distance. Using the mandatory adoption of International Financial Reporting Standards (IFRS) as an event that changed the accounting standards of various country-pairs, we examine how two sources of changes in accounting distance - (i) changes due to IFRS adoption of the investee and (ii) changes due to IFRS adoption in the investor's country - affect global portfolio allocation decisions. We find that the tendency to underinvest in investees with greater accounting distance significantly weakens when accounting distance is reduced either from an investee's IFRS adoption or from IFRS adoption in the investor's country. The latter finding holds despite the fact that IFRS adoption in the investor's country had no impact on the accounting standards under which the investee firms present their financial information; the only change is in the investor's familiarity with these standards. This suggests that differences in accounting standards affect investor demand by imposing greater information-processing costs on those less familiar with the reporting standards.

\footnotetext{
* The paper is a revised version of Gwen Yu's Ph. D. dissertation, previously titled "Accounting Standards and International Portfolio Holdings: An Analysis of Mutual Fund Holdings Following Mandatory Adoption of IFRS." We are grateful to Bin Ke (the editor) and an anonymous reviewer for their excellent suggestions. We thank Russ Lundholm, Ilia Dichev, Greg Miller, Venky Nagar, seminar participants at the 10th Darden International Finance Conference, 2009 FARS midyear conference, Harvard Business School, Northwestern University, NYU, UCLA, University of Michigan, University of Washington, Washington University, Wharton, and Yale University for their helpful feedback on the paper. Gwen Yu is grateful for the generous support of the Harvard Business School Division of Research. All errors are our own.

${ }^{1}$ Corresponding author: Harvard Business School, 383 Morgan Hall Soldiers Field, Boston, MA 02163, phone: 617496-6547, Fax: 617-496-7363, Email: gyu@hbs.edu

${ }^{2}$ University of Toronto, Rotman School of Management, Email: aida.wahid@ rotman.utoronto.ca
} 


\section{INTRODUCTION}

Theory suggests that in a world where financial markets are frictionless and perfectly integrated, all investors would hold a global market portfolio regardless of nationality (Grauer et al. 1976). However, this prediction is clearly at odds with the empirical data (Karolyi and Stulz 2003). A long stream of literature shows that investors significantly underweight foreign investments, a phenomenon referred to as home bias, which is consistently observed across different classes of investments and types of investors (Lewis 1999). One common explanation for the underweighting of foreign equities is that additional information costs exist when investing abroad (Kang and Stulz 1997; Ahearne et al. 2004). In this paper, we examine whether differences in local accounting standards and the changes induced by adopting a common international accounting standard affect the asset allocation decisions of global investors.

Accounting information constitutes one of the key inputs in portfolio investment decisions. Therefore, information presented under different accounting standards or practices is likely to be a source of additional processing costs. These processing costs consist of the direct costs of learning different accounting standards, as well as indirect costs that arise from the need to interpret financial statements in light of local practices. When accounting information is presented under standards that are more familiar to an investor, he/she may find it easier to process the information and is more likely to rely on public financial statements relative to private information.

The difficulty in examining the effect of accounting information on cross-border investment is that the extent to which accounting standards differ across countries is closely associated with other factors that affect investors' holdings decisions (Portes and Rey 2005; Leuz et al. 2010). Thus, attributing the full extent of the observed association solely to accounting standards neglects factors such as the transparency of a country's institutions (Gelos and Wei 2005) or firm-level 
incentives to select into a particular reporting regime (Covrig et al. 2007; Daske et al. 2013). However, a strong regulatory change recently occurred when a large number of countries mandated adoption of the International Financial Reporting Standards (IFRS) for most, though not all, of their local companies.

Using the firm-level holdings data of international mutual funds, we examine how reducing accounting distance through IFRS adoption affects the cross-border investment decisions of investors. We define accounting distance $(\mathrm{AD})$ as the difference in the accounting standards used by the investees and the accounting standards used in the investor's country. The bilateral nature of the accounting distance measure allows us to better understand the frictions arising from differences in accounting standards for at least two reasons. First, because it is a pairwise measure, we are able to document the relation between accounting distance and the degree to which investors from different countries have varying demands for a given investee. In contrast to extant studies that examine foreign investors broadly (Florou and Pope 2012), we show that investor demand can vary even among foreign investors, and more importantly, we explain this variation as a direct function of the $\mathrm{AD}$ between the investee and the investor's home country.

Second, the changes triggered by the global adoption of IFRS allow us to examine how changes in accounting distance affect global funds' asset allocation decisions. The changes analyses offer two advantages. First, by linking the changes in AD resulting from IFRS adoption to the changes in the investor's demand, we are able to address concerns due to correlated omitted variables that can be present in our levels analysis. Next, the bilateral nature of the AD measure allows us to differentiate between two different types of changes in AD: (i) changes resulting from the investee's IFRS adoption and (ii) changes resulting from the adoption of IFRS in the investor's country. The changes from IFRS adoption in the investor's country is of particular interest because they have no impact on the accounting standards under which the investee presents its financial 
information; the only change is to the investor's familiarity with these standards, i.e., the harmonization benefit (Bradshaw et al. 2004).

We start by examining whether 'local accounting distance' can explain the investor's tendency to underweight certain investee firms relative to the global portfolio. ${ }^{1}$ Local accounting distance is defined as the difference in the local accounting standards used by the investee and the standards used in the investor's country. For our dependent variable, we use a measure of the amount each firm is over or underweighted by investors, relative to the global portfolio. ${ }^{2}$ The unit of analysis is the firm-level investment weight disaggregated by the investor's country, i.e., the country-investor. For example, if a firm is held by investors from three different countries, such as Canada, Japan, and Switzerland, we construct three observations of over/underweights for this firm using its Canadian investors, its Japanese investors, and its Swiss investors. Disaggregating the observations by the investor's country (as opposed to aggregating all foreign investors) allows us to relate the investment weights of each country-investor to the accounting distance between the investor and the investee firm.

We find a positive relation between local accounting distance and the amount by which investors from certain countries, i.e., country-investors, underweight the firm in their portfolios. Our empirical test suggests that a one standard deviation increase in accounting distance, which is equivalent to the accounting distance between the U.S. and South Africa, leads investors to underweight firms by $19 \%$, relative to the sample mean. This finding holds after controlling for other well-known determinants of cross-border investments shown in the literature, such as geographic distance.

\footnotetext{
${ }^{1}$ Throughout the paper, we use the terms 'firm' and 'investee' interchangeably.

${ }^{2}$ See section III for a detailed computation of the over/underweight measures.
} 
Of course, the positive relation between accounting distance and the amount by which a country-investor underweights the investee may reflect the fact that accounting distance is closely related to other unobserved determinants of cross-border holdings not included in our estimation. In our main empirical tests, we therefore use the changes in $\mathrm{AD}(\triangle \mathrm{AD})$ triggered by the mandatory IFRS adoption to better identify the effect of accounting distance on cross-border investments. We measure $\triangle \mathrm{AD}$ as the difference between the investor-investee's local $\mathrm{AD}$ in the pre-adoption period and the investor-investee's AD post-IFRS adoption. ${ }^{3}$ Using this measure, we examine whether a greater reduction in accounting distance leads to a greater increase in investment weights. Our main prediction is that the increase in investment weights following IFRS adoption will be positively associated with the reduction in accounting distance between the investor and the investee.

It is important to note that the change in accounting distance can arise from two different IFRS adoption events. Accounting distance can change when the investee moves from local standards to IFRS and/or when the investor's country moves from local standards to IFRS. While several prior studies examine the changes arising from the investee firm's IFRS adoption (Daske et al. 2008; Shroff et al. 2013), the literature has focused less on the effect of IFRS adoption in the investor's country. This is partially due to the fact that only the investee's adoption leads to changes in the standards under which the firm provides its financial information. On the other hand, IFRS adoption on the investor's part only changes the investor's level of familiarity with the standards without the direct information effect of changing the investee's disclosure. In this study, we examine both adoption events and attempt to empirically disentangle their effects. In particular, we explore IFRS adoption in the investor's country as a unique setting that allows us to examine

\footnotetext{
${ }^{3}$ See section III and Appendix B for a detailed explanation of the methodology and computation of the measure.
} 
how increasing an investor's familiarity with the accounting standards affects the investor's demand, even when there is no direct information benefit.

We find that when accounting distance changes from the investee's IFRS adoption, the change in the investment weights is positively associated with how much the adoption event reduced the accounting distance between the investor and investee. This suggests that when investee firms switch from local standards to IFRS, they experience an increase in investment weights from investors for whom the switch led to the greatest reduction in accounting distance. We also find that when accounting distance changes due to IFRS adoption in the investor's country, investors increase their investment weights in investees with whom they now have reduced accounting distance. Note that this particular type of adoption requires no changes in the accounting standards that the investees use to present their information. It only changes the investor's familiarity with the standards. ${ }^{4}$ This finding suggests that reducing accounting distance, even where there is no informational benefit from changing the investee's disclosure, affects asset allocation decisions by presenting investors with financial information in a more familiar form.

Interestingly, we find that when accounting distance changes due to IFRS adoption in the investor's country, there is an asymmetric response to cases where the adoption reduces or increases the accounting distance relative to the pre-existing accounting distance. When IFRS adoption in the investors' country reduces accounting distance and investors become more familiar with the investee's accounting standards, investors respond by increasing their investment weights. However, when IFRS adoption in the investor's country increases accounting distance, we find no significant effect of investors withdrawing their capital. In other words, investors do not

\footnotetext{
${ }^{4}$ Empirically, because the IFRS adoption years were closely clustered across countries, many country-pairs are concurrently affected by both adoption events. This makes it challenging to identify the effect of IFRS adoption on the investor's part, independent of the investee's adoption and vice versa. For this reason, we limit our changes analyses to country-pairs where only one of the two countries adopts IFRS. In other words, we exclude country-pairs where both the investees and investors are classified as mandatory IFRS adopters. See the changes analyses in section IV.
} 
immediately leave the investees even when IFRS adoption indicates that they should now be less familiar with the investee's accounting standards. This is because the investors already know the firm's local GAAP. Even when the investors adopt the new IFRS standards, it is unlikely that they will immediately lose the level of familiarity they already had with the investee's existing accounting standards. The results suggests that once investors familiarize themselves with certain accounting standards, a persistent learning effect exists.

This paper contributes to the literature by showing how frictions generated by the differences in accounting standards influence cross-border investment decisions. Prior studies argue that differences in information acquisition costs across investors can drive much of the variation in cross-border holdings (Obstfeld and Rogoff 2001; Van Nieuwerburgh and Veldkamp 2009). However, the exact sources that lead to such information-processing costs remain less explored. We show that differences in local accounting standards can be a source of information costs even for mutual funds, which are among the more sophisticated users of financial information.

Our findings also add to the growing literature that examines how mandatory IFRS adoption affects investors' portfolio allocation decisions. Prior studies posit that IFRS adoption may affect investor demand by improving the precision of an average investor's information signal (Barth et al. 2008). Other studies show that IFRS adoption alters investor demand by providing information in a more familiar form, which in turn reduces the information asymmetry among investors (Barth et al. 1999; DeFond et al. 2011). We contribute to this literature by focusing on the latter. We show that changes in investor demand is directly associated with how much accounting distance is reduced between the investor and the investee. Unlike prior studies that focus on how IFRS adoption increases the demand of an average foreign investor (Florou and Pope 2012), we show that the changes in the demand will vary even among foreign investors and systematically by the level of AD changes from IFRS adoption. 
Finally, we add a methodological contribution to the literature by presenting a measure of accounting harmonization. Using an accounting distance measure modified from Bae et al. (2008), we present a measure of accounting harmonization triggered by IFRS adoption. Unlike prior IFRS studies that define accounting distance as the difference between the investee's home country GAAP and IFRS, we define accounting distance as the difference between the accounting standards used in the investors' and investee's home countries. The pairwise measure allows us to decompose the changes in AD into two components: (i) changes arising from an investees' IFRS adoption and (ii) changes arising from IFRS adoption in the investor's country. We use the changes in $\mathrm{AD}$ as our empirical proxy for accounting harmonization and add a discussion of the methodology and the key assumptions underlying the measure.

The organization of the rest of the paper is as follows. Section II describes the related literature and the hypotheses. Section III describes the sample and the empirical measures used in the study. Section IV presents the empirical specifications and results and section V includes additional analyses. Section VI concludes.

\section{PRIOR RESEARCH AND HYPOTHESES}

We examine whether differences in accounting standards are a source of information costs for investors. Accounting standards govern the rules with which public financial statements must comply. Thus, if financial information is presented under standards that are less familiar to investors, they may face additional difficulty in processing the information. Consistent with this, studies show that foreign investors prefer investing in firms with similar accounting standards because the similarity reduces investors' cost of acquiring/processing investees' information (Bradshaw et al. 2004; Chen et al. 2013). Similarly, Barth et al. (1999) analytically show that 
foreign investors prefer harmonized accounting standards because they reduce the costs of acquiring expertise that is comparable to that of local investors.

Anecdotal evidence also suggests that investors face barriers stemming from accounting standards differences. Practitioners argue that differences in accounting standards result in similar transactions being recorded differently, which make it difficult to compare financial statements across countries (Harris 1998; Hawkins 2001). In fact, institutional investors consider crosscountry differences in accounting standards to be enough of a barrier that they often hire external service providers that specialize in the adjustment process. ${ }^{5}$ The existence of such service providers reflects the non-trivial nature of this cost and the barrier it presents to cross-border investments.

If differences in accounting standards impose costs to investors, we predict that an investor's demand for an asset will be increasing with their level of familiarity with the firm's accounting standards. We argue that the investor's level of familiarity can be measured using the differences between the local accounting standards used in the reporting firm's and the investor's country. Our main prediction is that investors will have less demand for an asset with which they have greater accounting distance.

H1: There is a positive relation between local accounting distance and the amount by which a country-investor underweights the firm.

The difficulty in examining the effect of local accounting distance on investor demand is that other factors that determine accounting standards differences are closely related to country-level factors that also drive cross-country investment decisions. Several studies tackle this empirical issue by examining firms that change their accounting standards and isolate the effect of

\footnotetext{
${ }^{5}$ For example, Credit Suisse uses an in-house advisory service provider, HOLT, which, among other services, offers solutions that adjust for the differences in the local accounting standards across countries. The most common adjustment items are leases, pensions, R\&D, inflation, and goodwill accounting. In 2010, the aggregate adjustment resulted in a USD 14 trillion change in the total reported book assets of all companies in the HOLT database (Yu 2010).
} 
accounting standards from other country-level factors. For example, Covrig et al. (2007) use firms that voluntarily adopt international accounting standards and find an increase in the foreign ownership for such firms. Ammer et al. (2005) examine foreign firms that cross-list in the U.S. and find an increase in U.S. ownership, especially for those firms that show a higher commitment to more transparent information. The voluntary nature of the adoption process, however, may confound other factors that cause firms to select into a particular reporting regime, making it challenging to isolate the effect of the accounting standards.

More recently, studies have examined the mandatory adoption of IFRS, which offers a relatively exogenous setting for identifying the effects of accounting standards. Studies provide evidence of higher aggregate foreign ownership (DeFond et al. 2011; Florou and Pope 2012) and more frequent cross-border acquisitions (Louis and Urcan 2012) following mandatory IFRS adoption. Other studies, however, find no increase in aggregate ownership in equity holdings, but find an increase in debt holdings following IFRS adoption (Beneish et al. 2012). Such mixed evidence highlights the importance of better understanding the mechanism through which IFRS adoption changes foreign investor demand.

There are two potential channels through which mandatory IFRS adoption may lead to higher foreign investor demand. The first is through the improvement in information quality resulting from IFRS adoption, i.e., the information benefit. Studies find that following IFRS adoption, the reported earnings of a firm show less opportunism and exhibit higher earnings quality (Barth et al. 2008). Thus, if IFRS provides better disclosure relative to the local accounting standards, then IFRS adoption will reduce the noise in the information signals for an average investor. Consistent with this, Landsman et al. (2012) find that IFRS adoption leads to increased capital market 
consequences in the form of a greater price and volume reaction to a firm's earnings announcement.

Another mechanism through which IFRS adoption can change foreign investor demand is by providing information in a more familiar form, i.e., the harmonization benefit. Foreign investors prefer harmonized accounting standards because harmonization reduces the likelihood that local investors will have an information advantage over foreign investors who are less familiar with the local standards (Barth et al. 1999). If foreign investors face a higher cost in processing local accounting standards, harmonizing accounting standards can lead to increased demand by reducing foreign investors' information disadvantage. Thus, when firms adopt IFRS, this may lead to increased demand, especially from investors who are more familiar with IFRS than with the existing local standards.

The extant literature finds that IFRS adoption changes investor demand due to both effects the information and harmonization benefits. For example, Florou and Pope (2012) show that there is an increase in ownership of foreign investors following IFRS adoption. They interpret this as IFRS adoption providing greater benefits to a group of investors that is more likely to benefit from improved information quality vis-à-vis local investors. DeFond et al. (2011) find that IFRS adoption increases the foreign ownership of investees, especially where the adoption event made it easier to compare an investee's financial statements with those of its peer firms. Our paper supports these findings but with an important distinction. In contrast to extant studies that examine aggregate foreign investors in general, we examine the changes in foreign investor demand directly as a function of the processing cost that investors face and that arises from differences in accounting standards. We show that investor demand can vary even within foreign investors, and more importantly, as a direct function of the AD between the investee and the investor's home 
countries. To our knowledge, prior IFRS studies have not explored the investor's home country effect as a factor that affects information-processing costs.

By exploring variation in $\mathrm{AD}$ within foreign investors, we are able to focus on the role of investor's familiarity with the investee's standards as a source of investors' processing costs. When investee firms switch to IFRS, investors whose local accounting standards are more similar to IFRS will experience a larger reduction in AD. We examine whether investors that experience a greater reduction in $\mathrm{AD}$ show a greater increase in investor demand. If reduced $\mathrm{AD}$ lowers investors' processing costs, we predict that changes in demand due to IFRS adoption will be associated with the changes in AD experienced by different country-investors.

H2: Following an investee firm's mandatory IFRS adoption, there will be a greater increase in investment weights from country-investors that experience a greater reduction in accounting distance.

It is worth noting that accounting distance is a pairwise measure between the reporting firm and the investor. Thus, accounting distance can change either as a result of the investee's adoption or due to IFRS adoption in the investor's country. While an investee's IFRS adoption leads to changes in the accounting standards the firm uses to provide its financials, IFRS adoption on the investor's part imposes no direct changes on the standards under which the firm's financials are presented. The only change is to the investor's level of familiarity with these standards. The differing nature of these two adoption events provides us with an opportunity to better identify how IFRS adoption leads to increases in investor demand. We explore IFRS adoption in the investor's country as a unique settting that allows us to examine how reducing accounting distance, even with no changes in the information quality, affects investor demand.

In our next hypothesis, we separately examine investors' IFRS adoption to test the effect of reducing accounting distance (with no changes in information quality). If presenting investors with 
financial information in a more familiar form affects investors' asset allocation decisions, we expect that investors' tendency to underweight firms with greater local accounting distance will weaken from IFRS adoption in the investor's country. We predict that when accounting distance changes due to IFRS adoption in the investor's country, investors will increase their investment weights toward investees where the investor's own adoption event led to a greater reduction in accounting distance. ${ }^{6}$

H3: Following mandatory IFRS adoption in the investor's country, country-investors will show a greater increase in investment weights in the firms with which they experience a greater reduction in accounting distance.

\section{DATA AND EMPIRICAL MEASURES}

\section{Sample selection and descriptive statistics}

\section{Mutual fund holdings data}

Our sample covers a five-year period from 2003 to 2007. The holdings data of global mutual funds are from the International Thomson Financial Securities Mutual Fund database, which includes the security-level holdings of mutual funds. ${ }^{7}$ The securities held by the funds cover a worldwide range, with 52 destination countries. Several studies used the earlier years of the mutual fund holdings database aggregated at the country level (Chan et al. 2005; Hau and Rey 2008). In contrast, we use holdings at the security level to account for the variation in the IFRS adoption

\footnotetext{
${ }^{6}$ Finally, we note that another way in which harmonization can affect investor demand is through greater comparability. DeFond et al. (2011) show that harmonization increases foreign investor demand by increasing the ease with which firms can be compared. While the notion of comparability may be another mechanism through which the harmonization benefit is captured, prior studies examine the IFRS adoption event only from the investees' perspective. In this paper, we highlight the fact that distance can change from IFRS adoption in the investor's country. Nonetheless, to ensure that the harmonization effect documented in our study is not a subset of the comparability effect, throughout our analyses, we add the comparability effect from DeFond et al. (2011) as a control variable.

${ }^{7}$ For a comprehensive sample of global fund holdings, we merge the international database with the 13(f) filings of U.S. mutual funds, provided by Thomson Financial. 13(f) filings contain mostly domestic holdings of U.S. funds, which is not the main focus of our study. Nonetheless, it is important to include a complete set of holdings because the construction of global portfolio weights requires the total assets under management benchmark of both domestic and foreign holdings.
} 
process within each country. Because funds have different reporting frequencies, we undertake our analysis on an annual basis using the latest available reported holdings for each calendar year.

Table 1 reports the descriptive statistics for these mutual funds averaged over the sample period. We exclude funds in countries that invest only in domestic markets (Chan et al. 2005) and funds incorporated in offshore centers. ${ }^{8}$ After merging the fund holdings with financial data in Datastream, our final sample includes 35,215 funds domiciled in 36 different fund countries. Table 1, column 2 shows that our sample funds invest a total of 1.76 trillion USD in foreign securities. Funds domiciled in the U.S. hold $42.6 \%$ of the total global assets managed in foreign securities. U.S., U.K., and German funds together hold $67.5 \%$ of the global assets managed in foreign securities.

\section{Sample firms and mandatory IFRS adopters}

We collect our sample from Thomson Datastream using all firm-years from 2003 to 2007 . We eliminate firms missing the financial data included in our empirical model. This provides us with a sample of 14,599 firms from 46 countries. Table 2 shows the descriptive statistics of firms with financial data available in each country from 2003 to 2007. Panel A shows the firms in countries that mandated the adoption of IFRS reporting. Panel B presents the distribution of firms in nonadopting countries - countries that did not allow or require IFRS reporting during our sample period.

We classify a country as an IFRS adopter if during our sample period, it fully adopted IFRS, endorsed a version of IFRS that substantially complies with the version issued by the IASB (e.g., the EU), or chose to bring its national standards in line with IFRS (e.g., Australia). ${ }^{9}$ We also require the country to mandate the use of IFRS for the consolidated accounts of all major listed companies. Countries such as Canada, which permits but does not mandate the use of IFRS for their listed

\footnotetext{
${ }^{8}$ Offshore centers are as defined in the IMF's year 2000 report, Offshore Financial Centers IMF Staff Assessments. Whether financial centers also qualify as offshore funds is a matter of dispute in the literature. In this study, we do not consider major financial centers (e.g., Hong Kong, Singapore, Switzerland, and the United Kingdom) to be offshore funds because they play a major role in processing information in the capital market (Gehrig 1998).

${ }^{9}$ We exclude countries that adopted a significantly modified version of IFRS adjusted to local practices, e.g., China.
} 
companies, are not considered mandatory adopting countries. Also, countries that required the use of IFRS for some but not all of their listed firms are excluded from our mandatory adopting country sample. ${ }^{10}$ We collect the country's IFRS adoption status and the country-level adoption year from Ramanna and Sletten (2014). The authors collect country adoption years from the websites of two public audit firms ${ }^{11}$ and the World Bank's Reports on Observance of Standards and Codes (ROSC reports). We confirm our adoption dates with other data sources such as the country reports of the IFRS Adoption Research Group (http://www.adoptifrs.org).

We classify our firm sample into two groups. The first is the mandatory adopter group, defined as firms in countries that mandatorily adopted IFRS; these firms first adopted IFRS when the standards were mandated. Empirically, we consider a firm to be a mandatory adopter if it first adopted IFRS within two years after the standard's adoption at the country level. ${ }^{12,13}$ We exclude from the mandatory adopter sample firms that voluntarily adopted IFRS even before it was mandated. ${ }^{14}$ The non-adopter group is defined as firms in countries that did not adopt IFRS. As before, we exclude firms that voluntarily adopted IFRS in a non-IFRS adopting country. The final sample consists of 14,599 unique firms - 3,429 mandatory adopters and 11,170 non-adopters (Table 2, Panels A and B). In Table 3, we compare the characteristics of the two samples. Panel A shows

\footnotetext{
${ }^{10}$ Some countries required the use of either IFRS or U.S. GAAP for their listed firms, e.g., Switzerland. Following prior studies (Armstrong et al. 2010), we consider these countries mandatory adopting countries. Additional analysis (not tabulated) shows that our findings are robust to excluding Switzerland from the adopter sample.

${ }^{11}$ The two public audit firms include Deloitte Touche Tohmatsu (IASplus.com) and PricewaterhouseCoopers.

${ }^{12}$ The coding of firm-level accounting standards is from the classification provided in Thomson Datastream (WS07536). We follow the classification of Daske et al. (2008) to categorize accounting standards into IFRS and local GAAP.

${ }^{13}$ A number of firms continue to report under local standards even though their countries of incorporation mandated IFRS. Because the mandatory adoption of IFRS was limited to consolidated accounts, companies without consolidated accounts or those that qualify for the small-medium entity exemption continue to report under local accounting standards. Since the characteristics of such small-medium firms differ in terms of size and investor base (PricewaterhouseCoopers 2007), we exclude them from our analysis.

${ }^{14}$ Cross-listed U.S. firms have the option of providing financials under (1) U.S. GAAP or (2) IFRS with 20-f reconciliation to U.S. GAAP. To ensure that IFRS (and not U.S. GAAP) is the international standard under consideration, we drop cross-listed firms from the sample.
} 
that the mean firm size, measured using total assets, of the mandatory adopters is greater than the mean size of the non-adopters; however, the median size is comparable across the two groups.

\section{Empirical measures}

\section{Firm-level investment weight of international mutual funds}

We examine whether the accounting distance between an investor and an investee affects the amount by which a country-investor underinvests in an investee. Our unit of analysis is the investee and country-investor pairs. For example, if an investee firm is held by foreign investors from three distinct countries, we include three observations for the investee, one for each country-investor. Our dependent variable, a measure of the over/underinvestment of firm i in country (h)-investor's portfolio (weight $\mathrm{i}_{\mathrm{i}, \mathrm{h}, \mathrm{t}}$, is calculated according to the following two steps. First, for each year $t$, we compute the weight of firm $i$ in the portfolio of country(h)-investor as the following:

$$
\mathrm{W}_{\mathrm{i}, \mathrm{h}, \mathrm{t}}=\sum_{\mathrm{f}=1}^{\mathrm{h}} \mathrm{MV}_{\mathrm{i}, \mathrm{f}, \mathrm{t}} / \sum_{\mathrm{f}=1}^{\mathrm{h}} \mathrm{AUM}_{\mathrm{f}, \mathrm{t}},
$$

where $\mathrm{MV}_{\mathrm{i}, \mathrm{f}, \mathrm{t}}$ is the market value of firm i's float shares held by fund $\mathrm{f}$ in year $\mathrm{t}$. Following prior literature, we define float shares as market shares excluding shares held by block-holders with $5 \%$ or more of a firm's outstanding shares (Kho et al. 2009). ${ }^{15} \sum_{\mathrm{f}=1}^{\mathrm{h}} \mathrm{MV}_{\mathrm{i}, \mathrm{f}, \mathrm{t}}$ is the sum of firm i's MV held by all funds in country $\mathrm{h}$. $\mathrm{AUM}_{\mathrm{f}, \mathrm{t}}$ is the total of assets under management of fund $\mathrm{f}$ in year $\mathrm{t}$ and $\sum_{\mathrm{f}=1}^{\mathrm{h}} \mathrm{AUM}_{\mathrm{f}, \mathrm{t}}$ is the total AUM of all funds domiciled in country $\mathrm{h}$ in year $\mathrm{t}^{16}$

\footnotetext{
${ }^{15}$ We obtain the block-holder holdings using Worldscope's closely held variable for year-end. For firms with missing float data, we use the median float of the country-industry-year, or the industry-year when the former is not available. In untabulated analysis, we conduct our analysis after dropping firms with missing float data. Our inferences remain unchanged.

${ }^{16}$ The firm country of domicile is obtained from Thomson Datastream (GEOG).
} 
In Appendix A, we describe our measure of over/underweight using a hypothetical example. Assume firm i has outstanding float shares of 4 million. Shares of firm $\mathrm{i}$ are held by foreign investors from Canada, Japan, and Switzerland, which hold 1 million, 2 million, and 1 million of firm i's shares, respectively. The total AUM of all funds in Canada, Japan, and Switzerland is 800 million, 400 million, and 400 million, respectively. Thus, the weight of firm $\mathrm{i}$ in the portfolio of Canadian funds $\left(=\mathrm{w}_{\mathrm{i}, \text { Canada }}\right)$ is $1 / 800$. Similarly, the weight of firm $\mathrm{i}$ in the portfolios of Japanese $\left(=\mathrm{w}_{\mathrm{i}, \mathrm{Japan}}\right)$ and Swiss funds $\left(=\mathrm{w}_{\mathrm{i}, \text { Switzerland }}\right)$ are $2 / 400$ and $1 / 400$, respectively.

In the second step, we calculate the benchmark weight of firm $\mathrm{i}$ in year $\mathrm{t}\left(\mathrm{w}_{\mathrm{i}, \mathrm{t}}{ }^{*}\right)$ using firm i's market value relative to the market value of the global market portfolio.

$$
\mathrm{W}_{\mathrm{i}, \mathrm{t}}{ }^{*}=\mathrm{MV}_{\mathrm{i}, \mathrm{t}} / \sum_{\mathrm{i}} \mathrm{MV}_{\mathrm{i}, \mathrm{t}}
$$

where $\sum_{\mathrm{i}} \mathrm{MV}_{\mathrm{i}, \mathrm{t}}$ is the aggregate market value of all firms' float-adjusted shares in our sample at time t. This benchmark weight provides a CAPM-based benchmark holding under the assumption of no market frictions or information asymmetries (Ahearne et al. 2004).

Putting the two steps together, we can now construct a measure of the over/underinvestment of firm $\mathrm{i}$ in the country (h) investor portfolio by evaluating the weight of firm $\mathrm{i}$ in the portfolio of the country (h) investor $\left(\mathrm{w}_{\mathrm{i}, \mathrm{h}, \mathrm{t}}\right)$ relative to firm i's benchmark weight $\left(\mathrm{w}_{\mathrm{i}, \mathrm{t}}{ }^{*}\right)$ :

$$
\begin{aligned}
\text { Over/underweight }_{\mathrm{i}, \mathrm{t}, \mathrm{h}}= & \mathrm{w}_{\mathrm{i}, \mathrm{t}, \mathrm{h}} / \mathrm{w}_{\mathrm{i}, \mathrm{t}}{ }^{*} \\
& =\left(\sum_{\mathrm{f}=\mathrm{l}}^{\mathrm{h}} \mathrm{MV}_{\mathrm{i}, \mathrm{f}, \mathrm{t}} / \sum_{\mathrm{f}=1}^{\mathrm{h}} \mathrm{AUM}_{\mathrm{f}, \mathrm{t}}\right) /\left(\mathrm{MV}_{\mathrm{i}, \mathrm{t}} / \sum_{\mathrm{i}} \mathrm{MV}_{\mathrm{i}, \mathrm{t}}\right) .
\end{aligned}
$$

Returning to our example in Appendix A, if we assume that the market value of the global portfolio $\left(=\sum_{\mathrm{i}} \mathrm{MV}_{\mathrm{i}, \mathrm{t}}\right)$ is 1,600 million, the benchmark weight $\left(w_{i, t}{ }^{*}\right)$ of firm $\mathrm{i}$ is $1 / 400(=4 / 1,600)$. We can now construct a measure of the over/underweight of firm i for the Canadian, Japanese, and Swiss funds, respectively. Recall that weight of firm $i$ in the portfolio of the Canadian, Japanese, and the Swiss funds were 1/800, 2/400, and 1/400. Scaling the portfolio weights of each country- 
fund by the benchmark weight of 1/400 would give an over/underweight measure of $0.5,2$, and 1 . Therefore, we see that Canadian funds are underweighted, Japanese funds are overweighted, and Swiss funds are evenly weighted in investee firm i relative to the global portfolio.

Equation (3) shows, algebraically, how the over/underweight measure (over/underweight $t_{i, \mathrm{t}}$ ) differs from the percentage of a firm's market value held by investors, another metric frequently examined in prior literature (e.g., DeFond et al. 2011; Florou and Pope 2012). The percentage of ownership variable used in prior studies is equivalent to the percentage of firm i's shares held by funds in country $\mathrm{h}\left(=\sum_{\mathrm{f}=1}^{\mathrm{h}} \mathrm{MV}_{\mathrm{i}, \mathrm{f}, \mathrm{t}} / \mathrm{MV}_{\mathrm{i}, \mathrm{t}}\right)$ in equation (3). ${ }^{17}$ Our measure is observationally equivalent to the percentage of firm i's shares held by country $h$ funds $\left(=\sum_{\mathrm{f}=1}^{\mathrm{h}} \mathrm{MV}_{\mathrm{i}, \mathrm{f}, \mathrm{t}} / \mathrm{MV}_{\mathrm{i}, \mathrm{t}}\right)$ divided by the weight of country-funds' AUM relative to the global market portfolio $\left(=\sum_{\mathrm{f}=1}^{\mathrm{h}} \mathrm{AUM}_{\mathrm{f}, \mathrm{t}} / \sum_{\mathrm{i}} \mathrm{MV}_{\mathrm{i}, \mathrm{t}}\right)$. Thus, the measure of over/underweight evaluates the percentage of ownership of each country-fund after considering the size of the country-funds' assets in the global market portfolio.

There are two advantages of this measure over the percentage of ownership used in prior studies. First, by considering the changes in the weight of the country-funds' assets in the global market portfolio $\left(=\sum_{\mathrm{f}=1}^{\mathrm{h}} \mathrm{AUM}_{\mathrm{f}, \mathrm{t}} / \sum_{\mathrm{i}} \mathrm{MV}_{\mathrm{i}, \mathrm{t}}\right)$, our over/underweight measure effectively controls for changes in the asset size of the investing fund. In other words, because we define the denominator relative to the fund's capital rather than to the outstanding share of the underlying security, the over/underinvestment weight adjusts for changes in ownership that may be due to funds rebalancing their portfolio when there are changes in the own AUM. ${ }^{18}$ The second advantage of the over/underweight measure is that the predicted value of the investment weight has a theoretical

\footnotetext{
${ }^{17}$ That is, the percentage of ownership held by all foreign funds would be equivalent to considering all non-domestic funds as one country-investor group.

${ }^{18}$ To go back to our earlier example from Appendix A, suppose the AUM of Japanese funds increased. Portfolio rebalancing will lead Japanese funds to hold a greater market value of firm i. Increased holdings due to this portfolio rebalancing would result in an increase in the percentage ownership of Japanese funds while the over/underweight measure will remain unchanged.
} 
value of one regardless of the level of aggregation or the underlying security. If the measure is greater (less) than one, this indicates that a firm is over (under)weighted in the country-investor's portfolio relative to the global benchmark.

Table 3, Panel B reports the descriptive statistics for the over/underweight of countryinvestors for the firms in our sample in the pre-adoption period. The unit of observation is each country-investor that holds the firm. We exclude domestic investors and only include foreign country-investors. In our main empirical tests, we use firm-level observations disaggregated by the investor's country, i.e., the country-investor. Thus, if a firm is held by investors from three different countries, we include three observations of over/underweights for this firm. Panel B shows that the median firm-level investment weight of all country-investors is 0.24 , which is clearly below the theoretical benchmark of one. Also, approximately $75 \%$ of the country-investors' investment weights show a value lower than one, consistent with investors underweighting foreign assets when making global portfolio allocation decisions.

Panel B of Table 3 shows that the tendency to underweight firms in the country-investor's portfolio is related to whether a firm adopts IFRS. The median underweight for the non-adopters sample is higher $(0.79=1-0.21)$ than the median underweight of the mandatory adopters $(0.67=1$ 0.33). In our empirical test, we examine whether the investment weight of each country-investor relates to the local accounting distance investors face when investing in the firm.

\section{Accounting distance and mandatory IFRS adoption}

In our main analysis, we use a pairwise measure of differences in local accounting standards between two countries to test whether differences between the investee's and the investor's home countries' GAAP can explain the amount by which a country-investor underweights the firm. The 
measure of local accounting distances $\left(\mathrm{LAD}_{\mathrm{i}, \mathrm{h}}\right)$ is based on Bae et al. (2008) and modified to measure the difference in the local accounting standards between two countries. Bae et al. (2008) construct a measure of the degree to which local accounting standards deviate from IFRS based on a survey of seven global accounting firms (Nobes 2002). ${ }^{19,20}$ Their two-year survey presents a detailed comparison of different accounting rules, which are classified as either the same as or different from IFRS. Bae et al. (2008) identify 21 accounting standards that show sufficient variation across countries and that the prior literature has recognized as key accounting items (Comprix et al. 2003).

We construct a composite measure of local accounting distance for each country-pair by adding the 21 binary values assigned after comparing the individual accounting standards. Bae et al. (2008) consider two accounting standards to be similar when both sets of rules either comply with IFRS or follow local standards that are non-compliant with IFRS. However, it is unclear whether a pair of non-compliant local accounting standards would necessarily be more similar to each other than a pair of local accounting standards would be if only one of them complies with IFRS. Thus, we modify Bae et al. (2008) so that we consider two non-compliant local accounting standards to be similar only if the two countries have the same legal origin. This provides a

\footnotetext{
${ }^{19}$ A handful of studies develop measures of differences in accounting information across countries. The first set of studies examines differences in inputs, such as choices of accounting standards/methods. Bradshaw and Miller (2007) measure conformity with U.S. GAAP at the firm level based on 13 accounting method choices using data from Worldscope. Hung (2001) computes an index by comparing accounting standards in 11 areas for 21 countries based on the 1993 International Accounting Summaries. However, neither of these is a country-pair measure, as used in our study. The second set of studies constructs differences in accounting information based on reported outputs, such as the properties of reported earnings. Ball et al. (2003) compare the timeliness of earnings in reporting bad news across several countries; they document large variations even within countries that share relatively common accounting systems. Similarly, De Franco et al. (2011) employ an output-based measure that uses the association between economic events and reported earnings. The authors state that input-based measures can be irrelevant from the users' perspective, especially when different inputs produce the same output (p. 9). Because the focus of our study is on the role of accounting standards, not on comparability, we limit our attention to input-based measures.

${ }^{20}$ GAAP 2001 (Survey of National Accounting Rules Benchmarked Against International Accounting Standards) is a comprehensive two-year study that presents a detailed comparison of each local GAAP on 80 different accounting dimensions. Comparisons of each local standard reflect both the standards' actual differences and the differences perceived by investors. Ding et al. (2007) use this survey to explore the causes that drive the differences between IAS rules and domestic standards as well as their consequences.
} 
measure of accounting distance across all country-pairs using a scale of 0 to 21 . Our decision to use legal origin to proxy for accounting standards differences is derived from a long literature that identifies legal systems and origins as a fundamental driver of accounting standards differences. ${ }^{21}$ Appendix B.1 presents our measure of local accounting distance (LAD $\left.\mathrm{LA}_{\mathrm{i}, \mathrm{h}}\right)$ for all the country-pairs included in our sample.

Note that IFRS adoption can change the accounting distance between two countries in two ways. First, when an investee firm i adopts IFRS, the accounting distance will change from the distance between the two local accounting standards ( $\left.\mathrm{LAD}_{\mathrm{i}, \mathrm{h}}\right)$ to the distance between IFRS and the local accounting standards of the fund $\left(\mathrm{AD}_{\mathrm{h}}\right)$. We consider this as the change in accounting distance due to the investee's IFRS adoption $\left(\triangle \mathrm{AD} \_\mathrm{FIRM}_{\mathrm{i}, \mathrm{h}}\right)$. Second, when IFRS is adopted only in the country where the fund (i.e., the investor) is domiciled, the accounting distance will change from the distance between the two local accounting standards $\left(\mathrm{LAD}_{\mathrm{i}, \mathrm{h}}\right)$ to the distance between IFRS and the local accounting standards of the investee $\left(\mathrm{AD}_{\mathrm{i}}\right)$. We consider this as the change triggered by the investor's IFRS adoption $\left(\triangle \mathrm{AD}_{-} \mathrm{FUND}_{\mathrm{i}, \mathrm{h}}\right)$. Therefore, we define our measures of the two different changes in accounting distances as:

$\Delta \mathrm{AD} \_F I R M_{\mathrm{i}, \mathrm{h}}=\mathrm{AD}_{\text {post }}-\mathrm{AD}_{\text {pre }}=\mathrm{AD}_{\mathrm{h}}-\mathrm{LAD}_{\mathrm{i}, \mathrm{h}}$, from firm i's mandatory IFRS adoption, and $\triangle \mathrm{AD} \_F U N D_{\mathrm{i}, \mathrm{h}}=\mathrm{AD}_{\text {post }}-\mathrm{AD}_{\text {pre }}=\mathrm{AD}_{\mathrm{i}}-\mathrm{LAD}_{\mathrm{i}, \mathrm{h}}$, from mandatory IFRS adoption in country $\mathrm{h}$, where the fund is domiciled. ${ }^{22}$

In Appendix B, we present the detailed measures (Appendix B.1) and the methodology (Appendix B.2) used to derive the change in accounting distance for each country-pair. For

\footnotetext{
${ }^{21}$ For example, Seidler (1967) discusses how the process through which accounting standards emerge in civil law countries and code law countries shows stark differences. Similarly, Salter and Doupnik (1992) show that the classification of accounting systems best corresponds to the common vs. code law dichotomization. In later analysis, we examine the sensitivity of our results to an alternative measure that does not rely on this assumption; our findings are robust (See section V).

${ }^{22}$ The definition shows that when both the firm and the fund adopt IFRS and the remaining accounting distance is zero, the $\triangle \mathrm{AD}$ measure takes the value of $-\mathrm{LAD}_{\mathrm{i}, \mathrm{h}}\left(=\mathrm{AD}_{\text {post }}-\mathrm{AD}_{\mathrm{pre}}=0-\mathrm{LAD}_{\mathrm{i}, \mathrm{h}}\right)$.
} 
example, our data shows that the local accounting distance $\left(\mathrm{LAD}_{\mathrm{i}, \mathrm{h}}\right)$ between Denmark and Canada is 14. When firms in Denmark adopted IFRS in the year 2005, the accounting distance for Canadian funds investing in Danish firms was reduced by 9, from 14 to 5 , representing a move along the horizontal axis (see Appendix B.1). Likewise, when IFRS was adopted in Denmark, the accounting distance for Danish funds investing in Canadian firms was reduced by 3, from 14 to 11 , representing a move along the vertical axis. In contrast to prior studies that focus on the horizontal axis $\left(\triangle \mathrm{AD} \_\mathrm{FIRM}_{\mathrm{i}, \mathrm{h}}\right)$, our empirical tests separately examine the two different types of AD changes: (i) change due to the firm's IFRS adoption $\left(\triangle \mathrm{AD} \_\mathrm{FIRM}_{\mathrm{i}, \mathrm{h}}\right)$ or (ii) change due to the adoption of IFRS in the investor's country $\left(\triangle \mathrm{AD} \_F U N D_{i, h}\right)$.

\section{EMPIRICAL TESTS AND RESULTS}

We test our main predictions using both a levels and a changes analysis. Briefly, the levels analysis tests our first hypothesis, that local accounting distance is positively associated with the underweighting of an investee. For the levels analysis, we limit our sample period to the years prior to IFRS adoption and focus on the effect of accounting distances from differences in local accounting standards. We also exploit the changes in AD stemming from IFRS adoption. The changes analyses are direct tests of our second and third hypotheses, which examine the adoption effect of the investee firm and the investor, respectively. However, because the IFRS adoption dates of most countries were clustered around one specific year, 2005, many country-pairs were concurrently affected by both adoption events. This makes it challenging to identify the effect of the investor's IFRS adoption, independent of the investee's adoption (and vice versa). For this reason, we limit our changes analyses to the country-pairs where only one party - either the investor or the investee - changes its accounting standards to IFRS. 


\section{Levels analysis: The effect of local accounting distance on investment weight}

We first examine the effect of local accounting distances on investment holdings prior to IFRS adoption. If differences in accounting standards impose processing cost for foreign investors, we predict a positive relation between local accounting distance and the amount by which a country-investor underweights the firm.

Using our pairwise measure of differences in local accounting standards between two countries $\left(\mathrm{LAD}_{\mathrm{i}, \mathrm{h}}\right)$, we test whether the country-pair differences between an issuer's (investee's) local accounting standards and an investor's local accounting standards can explain the amount that a country-investor underweights the investee. We estimate the following regression model using ordinary least squares (OLS) with investee firms indexed as i, country-funds as h, and each year in the sample as t.

Over/underweight $\mathrm{i}_{\mathrm{i}, \mathrm{t}, \mathrm{t}}=\beta_{0}+\beta_{1} \cdot \mathrm{LAD}_{\mathrm{i}, \mathrm{h}}+\sum_{\mathrm{p}=1} \lambda_{1, \mathrm{p}} \cdot$ Country-pair control

$$
+\sum_{\mathrm{q}=1} \lambda_{2, \mathrm{q}} \text {. Country controls }+\sum_{\mathrm{m}=1} \lambda_{1, \mathrm{~m}} \cdot \text { Firm controls }+\varepsilon_{\mathrm{i}, \mathrm{h}, \mathrm{t} .}
$$

Over/underweight $t_{i, h, t}$ is the investment weight a country-investor $h$ places on firm $i$ in year $t$ relative to the global market portfolio. If the over/underweight measure is greater (less) than one, this indicates that a firm is over (under)weighted in the country-investor's portfolio relative to the global benchmark. $\mathrm{LAD}_{\mathrm{i}, \mathrm{h}}$ measures the difference between the local accounting standards of the investee's country and the investing fund's countries before IFRS adoption. If differences in accounting standards represent barriers to cross-border investment, then hypothesis 1 predicts the $\beta_{1}$ coefficient will be negative.

We estimate equation (4) using the mandatory adopter sample in the pre-IFRS adoption period. Theoretically, we should also observe the effect of LAD in the non-adopter sample. We repeat the analysis using the non-adopter sample. We predict that the $\beta_{1}$ coefficient will be negative for both the mandatory adopter (pre-adoption) and the non-adopter sample. 
We include a rich set of country- and firm-level controls from prior literature to account for other determinants of cross-border holdings that can affect the portfolio allocation of mutual funds. Country-level controls include both macroeconomic and policy factors that influence decisions to invest in a given country. Specifically, to capture macroeconomic performance, we include the number of listed companies (\# of listed companies), foreign direct investment flows (FDI flows), market return (Index returns), GDP growth (GDP growth), and GDP per capita. We also include stock market turnover, annual inflation, and the real exchange rate to account for appreciation of the local currency that can affect the costs of investing abroad (Reinhart and Rogoff 2003).

The pairwise design allows us to control for other country-pair-level determinants of crossborder holdings between the two countries. Barriers that create frictions in bilateral holdings go beyond accounting standards. We control for well-known barriers such as geographic distance, a proxy for the cost of information acquisition, and economic distance (Net trade), measured as the log of total net exports between two countries in billions of U.S. dollars. We include a control for language distance, using a language distance measure of the dominant language used in the investor's and the investee's respective countries, as designed by Lewis (1999). See Appendix C for detailed definitions and the sources of each control variable.

Because the estimation of equation (4) uses firm-level holdings, we include firm-level attributes that prior literature has shown affect cross-border holdings (Aggarwal et al. 2005; Barth et al. 2008). Firm-level controls include measures of firm size (Log total assets), performance (ROA, Dividend yield), capital structure (Leverage), and growth opportunities (Market-to-book). We also include a measure of governance to control for foreign investors' preference for wellgoverned firms (Leuz et al. 2010), an indicator variable for firms audited by a Big Five audit firm (Big five auditor), and firms' information environment (\# of analysts). We include the extent of 
foreign activities, measured using the firm's total (or identifiable) assets of all non-domestic operations (Foreign assets). Additionally, we control for the firm's prior performance by including its stock returns for the prior year (Stock returns), the standard deviation of monthly returns over the previous year (Stock volatility), and the prior year sales growth (Sales growth). We include the comparability measure from DeFond et al. (2011), which captures the accounting standards used by the firm's industry peers firms (Comparability). The variable captures the level of uniformity in the firm's information disclosure and is calculated as the number of peers in the firm's countryindustry that use the same reporting standards as the firm. Finally, we include country- and industry-year indicators to control for country- and industry-specific differences that may influence mutual funds' portfolio allocation decisions. The models are estimated using robust standard errors clustered by the country-pair of the investee's and the investor's countries.

Table 4 shows the results of estimating equation (4). Because our goal in the levels test is to examine the effect of local accounting distances, we limit the sample to firm-years before IFRS was mandated. Column 1 shows the estimated results using only mandatory adopters in the preadoption period. The estimated coefficient on $\mathrm{LAD}_{\mathrm{i}, \mathrm{h}}$ is negative and significant $\left(\beta_{1}=-0.088\right.$, $\mathrm{t}$-stat $=-1.969$ ), suggesting that investors allocate less weight to firms located in countries with greater local accounting distance. The estimated coefficient suggests that firms have 19\% lower investment weights from funds in countries with a one standard deviation (=4.37) higher level of the $\mathrm{LAD}_{\mathrm{i}, \mathrm{h}}$ measure, relative to the sample mean investment weights $(=1.99)$.

In column 2, we present the estimated coefficient using the non-adopter sample with all years in our sample period. ${ }^{23}$ We find that the estimated coefficient on LAD $_{\mathrm{i}, \mathrm{h}}$ is again negative and

\footnotetext{
${ }^{23}$ While the LAD for the non-adopters sample will not change as a result of the firm's adoption, it can still change when the investor's country adopts IFRS standards. We adjust our LAD measure to account for the time-variation in the LAD measure from the investee's adoption of IFRS. Thus, the LAD measures for the non-adopters vary over time.
} 
significant $\left(\beta_{1}=-0.064\right.$, $\mathrm{t}$-stat $\left.=-1.650\right)$. Also, finding a significant effect in the non-adopter group supports our finding in column 1. It further suggests that the effect of AD shown in the mandatory adopter group (pre-adoption) is not an artifact of the selection effect of the type of countries that later mandate IFRS. The overall message in columns 1 and 2 is that LAD has a significant impact on the underweighting by foreign investors and that it captures a type of information barrier that explains the variation in cross-border holdings beyond the determinants found in previous studies. We next turn to the changes analysis and directly examine whether the changes in accounting distance following the mandatory adoption of IFRS lead to changes in foreign investors' demand.

\section{Changes analyses}

We use a changes specification and relate the changes in investment weights to the changes in accounting distance resulting from IFRS adoption. We propose a measure of accounting harmonization (resulting from IFRS adoption) using the concomitant changes in AD. The advantage of this measure is that it allows one to decompose the harmonization effect into two components: (i) the changes stemming from an investees' IFRS adoption $\left(\triangle \mathrm{AD} \_F I R M_{\mathrm{i}, \mathrm{h}}\right)$ and (ii) the changes due to IFRS adoption in the investor's country $\left(\triangle \mathrm{AD}_{-} \mathrm{FUND} \mathrm{i}_{\mathrm{i}, \mathrm{h}}\right)$.

\section{Effect of local accounting distance following the firm's mandatory IFRS adoption}

We examine how the changes in AD stemming from a firm's IFRS adoption affect the investment weights. This tests our second hypothesis, which predicts that a reduction in AD due to an investee's IFRS adoption will lead to a reduction in the amount by which a country-investor underweights investees in its market portfolio. We test this prediction using the regression model in equation (5).

$\begin{aligned} \Delta \text { Over/underweight }_{\mathrm{i}, \mathrm{h}}= & \beta_{0}+\beta_{1} \times \Delta \mathrm{AD}_{-} \text {FIRM }_{\mathrm{i}, \mathrm{h}}+\sum_{\mathrm{q}=1} \lambda_{2, \mathrm{q}} \times \Delta \text { country controls } \\ & +\sum_{\mathrm{m}=1} \lambda_{1, \mathrm{~m}} \times \Delta \text { Firm controls }+\varepsilon_{\mathrm{i}, \mathrm{h} .}(5)\end{aligned}$ 
$\Delta$ Over/underweight $\mathrm{i}_{\mathrm{h}, \mathrm{t}}$ is the change in the average investment weights of firm $\mathrm{i}$ held by countryfund $\mathrm{h}$ two years before and after IFRS adoption. If a firm does not appear in the holdings dataset pre-adoption and appears only in the post-adoption period, we assume that no foreign funds held the firm during the pre-adoption period. ${ }^{24} \mathrm{We}$ apply this assumption symmetrically for the postadoption period. $\triangle \mathrm{AD} \_\mathrm{FIRM}_{\mathrm{i}, \mathrm{h}}$ is the changes in accounting distance between firm $\mathrm{i}$ and countryinvestor $\mathrm{h}$ following the mandatory IFRS adoption of firm $\mathrm{i}$. The measure takes a lower value if the firm's IFRS adoption leads to a greater reduction in accounting distance.

All country-level and firm-level controls are specified as changes in the average values two years before and after the firm's IFRS adoption. For the comparability measure, we follow DeFond et al. (2011) and define changes as a ratio. This ratio is calculated as the number of firms in each industry that used IFRS in the post-adoption period divided by the number of firms in each country-industry that maintained the accounting standard firm i used in the pre-adoption period. We exclude control variables with no time-series variation (e.g., geographic distance). We include country- and industry-year fixed effects, and estimate the model using OLS regressions and robust standard errors clustered by country-pairs.

We predict that when AD changes from a firm's IFRS adoption $\left(\triangle \mathrm{AD} \_F I R M_{\mathrm{i}, \mathrm{h}}\right)$, there will be a greater increase in investment weights from those countries that experienced a greater reduction in accounting distance, that is, a negative $\beta_{1}$. One potential concern with the $\beta_{1}$ estimates is that they may be confounded by the effect of the fund's IFRS adoption as well as the firm's adoption. This is because many funds in our sample are domiciled in countries that concurrently adopted IFRS. To cleanly separate the effect of the investee firm's IFRS adoption from the fund's adoption,

\footnotetext{
${ }^{24}$ Because funds are not required to report holdings for firms that they do not hold, excluding firms with missing holdings in the pre-period will result in dropping the bulk of firms that first see foreign investment following IFRS adoption.
} 
we exclude pair-observations where both investee and investors adopt IFRS. In other words, we estimate equation (5) using the sample where only the investee firm adopted IFRS. ${ }^{25,26}$

Table 5 reports the estimated results of equation (5). The first column shows that the $\beta_{1}$ coefficient on $\left(\triangle \mathrm{AD} \_\mathrm{FIRM}_{\mathrm{i}, \mathrm{h}}\right)$ is negative and statistically significant $\left(\beta_{1}=-0.034\right.$, t-stat $\left.=-2.944\right)$. The estimated coefficient in column 1 suggests that, on average, firms experience 0.15 less underinvestment relative to the global portfolio when $\mathrm{AD}$ decreases by one standard deviation $(=4.37)$ due to an investees' IFRS adoption $\left(\triangle \mathrm{AD} \_\mathrm{FIRM}_{\mathrm{i}, \mathrm{h}}\right)$. The coefficients on the controls are significant for several variables. Changes in firm growth and growth opportunities, proxied by sales growth (t-stat of 1.928) and the market to book ratio (t-stat of 1.957) respectively, show a greater association with changes in investment weights. Conversely, an increase in dividend yield is associated with a decrease in the investment weight allocated to a firm, consistent with the notion that investors focus on firms with the greatest growth opportunities. Changes in other firmlevel variables are not associated in a statistically significant way with the changes in investment weight allocations. The estimated coefficients on the changes in comparability measure is negative but statistically insignificant. $^{27}$

\footnotetext{
${ }^{25}$ By excluding the investor-investee pairs with concurrent IFRS adoption, we could be dropping the pairs with the greatest harmonization effect, i.e., perfect convergence. This selection effect will bias us against finding a significant harmonization effect. We note that when we include all country-funds in our estimation, we find largely similar effects with increased significance.

${ }^{26}$ The countries included in our regression model where firms IFRS adoption was mandatory are Australia, Austria, Belgium, the Czech Republic, Denmark, Estonia, Finland, France, Germany, Greece, Hungary, Ireland, Italy, Luxembourg, the Netherlands, New Zealand, Norway, Poland, Portugal, South Africa, Spain, Sweden, Switzerland, the United Kingdom, and Venezuela.

${ }^{27}$ We note, however, that our empirical design differs from that of DeFond et al. (2011) in several ways. First, we exclude (in our changes analysis) the pairs where both the investee and the investors adopt IFRS. Thus, we may be excluding the observations that show the greatest effect of comparability, as defined in DeFond et al. (2011). Second, where DeFond et al. (2011) focus only on the European Union, our study encompasses the entire world. Thus, it is possible that the effect of comparability is reduced outside of the E.U. sample. This is largely consistent with DeFond et al. (2011), as the authors find that uniformity only matters when the credibility of local institutions is high. That is, if countries outside of the E.U. have weaker enforcement, it could explain the lack of significance in our sample.
} 
In column 2, we examine a sub-sample of the changes in $\left(\triangle A D \_F I R M_{i, h}\right)$ that resulted in a reduction in $\mathrm{AD}$. These are the pair-observations where the $\triangle \mathrm{AD}_{-} \mathrm{FIRM}_{\mathrm{i}, \mathrm{h}}$ measure takes a negative value. We find similar effects with greater economic magnitude. Overall, the findings in Table 5 confirm our second hypothesis, showing that the increased investment weight following a firm's adoption of IFRS is driven by funds that experience a greater reduction in accounting distance.

\section{Effect of local accounting distance following IFRS adoption in the investor's country}

We examine whether changes due to IFRS adoption in the investor's country can also lead to effects similar to the changes due to the firm's IFRS adoption. The reduction in accounting distance on the part of the investors is a unique event that allows us to examine the harmonization benefit while holding the information benefit constant. This is because when the investor's home country adopts IFRS, no changes occur in the accounting standards under which the firm's information is prepared. The adoption only makes investors more familiar with the accounting standards firms use to disclose their information. This allows us to attribute the changes in investment weights to the harmonization benefit after controlling for the information benefit. Such findings therefore provide clean evidence of the harmonization benefit, which could not be documented by prior studies that focused exclusively on the firm's IFRS adoption.

We use equation (6) to examine the effect of IFRS adoption in the investor's country h. We employ a model similar to equation (5), but use changes in AD from the fund's IFRS adoption $\left(\triangle \mathrm{AD} \_F U N D_{i, h}\right)$, instead of the changes from the firm's adoption.

$\begin{aligned} \Delta \text { Over/underweight }_{\mathrm{i}, \mathrm{h}}= & \beta_{0}+\beta_{1} \times \Delta \mathrm{AD}_{-} \mathrm{FUND}_{\mathrm{i}, \mathrm{h}}+\sum_{\mathrm{q}=1} \lambda_{2, \mathrm{q}} \times \Delta \text { country controls } \\ & +\sum_{\mathrm{m}=1} \lambda_{1, \mathrm{~m}} \times \Delta \text { Firm controls } \\ & +\varepsilon_{\mathrm{i}, \mathrm{h} .}(6)\end{aligned}$ 
$\triangle \mathrm{AD} \_F U N D_{i, h}$ is the change in accounting distance following mandatory IFRS adoption in the fund's country h, and takes a lower value if the IFRS adoption leads to a greater reduction in accounting distance. A negative (positive) value of the $\triangle \mathrm{AD} \mathrm{FUND}_{\mathrm{i}, \mathrm{h}}$ measure suggests that the adoption event resulted in less (greater) accounting distance between the investor and the investee.

We specify the changes in the country- and firm-level variables as changes in the average values two years before and after IFRS adoption in the fund's country. For the comparability measure, we calculate the changes as the \# of firms in each industry using IFRS in the postadoption period divided by the \# of firms in each country-industry using the same accounting standard used in the fund's country pre-adoption. For the country-level controls, we use the country-level measure based on where the fund is domiciled. As before, we include country- and industry-year fixed effects, and estimate the model using OLS regressions and robust standard errors clustered by country-pairs of the firm's investor's countries.

Our main prediction is that the greater reduction in AD due to an investor's IFRS adoption will lead to a greater decrease in the amount by which a country-investor underweights the investees in their market portfolio, that is, $\beta_{1}<0$. This is a direct test of hypothesis 3 . Mirroring our earlier analysis in Table 5, we estimate equation (6) using observations where only the investor's country adopted IFRS; we exclude observations where the investee firm also mandatorily adopted IFRS. As explained earlier, we impose this sample restriction to cleanly identify the effect of the investor's adoption without confounding the investee-firm's adoption effect. ${ }^{28}$

Recall that IFRS adoption in the investor's country is an event that changes the investor's (i.e., fund's) familiarity with the accounting standards investees use to disclose their information.

\footnotetext{
${ }^{28}$ Investor countries that mandatorily adopted IFRS and are included in our regression model are Australia, Austria, Belgium, the Czech Republic, Denmark, Estonia, Finland, France, Germany, Greece, Hong Kong, Hungary, Ireland, Italy, the Netherlands, New Zealand, Norway, Poland, Portugal, South Africa, Spain, Sweden, Switzerland, and the United Kingdom.
} 
There is no change in the accounting standards under which the investee's information is prepared. When changes in $\mathrm{AD}$ are caused by changes in the standards used in the investor's country, it is conceivable that the direction of the change will matter. An adoption event that reduces accounting distance $\left(\triangle \mathrm{AD} \_\mathrm{FUND}_{\mathrm{i}, \mathrm{h}}<0\right)$ is likely to increase investor demand. However, an adoption event that increases accounting distance $\left(\triangle \mathrm{AD} \_\mathrm{FUND}_{\mathrm{i}, \mathrm{h}}>0\right)$ is unlikely to cause an immediate reduction in investor demand. This is because investors already know the firm's local GAAP. While the AD measure may have increased when the investor moved to IFRS, it is unlikely that investors will immediately lose the level of familiarity they already have with the existing GAAP used by the firm. We therefore expect changes in $\mathrm{AD}$ to lead to changes in investor demand only when the adoption event increases the investor's familiarity with the investee's standard $\left(\triangle \mathrm{AD}_{-} \mathrm{FUND}_{\mathrm{i}, \mathrm{h}}<0\right)$.

Table 6 shows the results of estimating equation (6). In column 1, we use the entire sample of both increases and decreases in $\mathrm{AD}$. We find that the effect of changes in AD due to IFRS adoption in the investor's country is negative yet not statistically significant $\left(\beta_{1}=-0.005\right.$, $\mathrm{t}$-stat $=$ 0.396). We test whether the direction of the $\mathrm{AD}$ change will lead to differential effects. In column 2, we estimate equation (6) using only adoption events that increased the investors' familiarity with an investee's reporting standards, that is, $\triangle \mathrm{AD} \_F U N D_{i, h}<0$. We find that the coefficient on AD_FUND ${ }_{i, h}$ is now negative and statistically significant $\left(\beta_{1}=-0.038\right.$, t-stat $\left.=-2.893\right)$. Once we restrict the sample to adoption events that increased an investor's familiarity with investees' standards, we find strong evidence that the adoption event leads to changes in investment weights. However, when IFRS adoption in the investor's country increases accounting distance, we find no evidence of investors immediately withdrawing their capital. The asymmetric responses to adoption events that increase vs. decrease AD suggest that once investors (i.e., funds) become 
familiar with a certain standard a persistent learning effect exists, at least within our two-year sample period.

We also note that the economic magnitude of the $\beta_{1}$ coefficient in column $2(=-0.038)$ is weaker than the -0.064 estimated in the analysis of the $\Delta \mathrm{AD}_{-} \mathrm{FIRM}_{\mathrm{i}, \mathrm{h}}$ in Table 5 , column 2 . This suggests that while increases in familiarity with an investee's accounting standards are likely to have a strong effect on investment demand (Table 6, column 2), the magnitude is less than the effect that would be observed when the AD change is caused by a change in the accounting standards under which the investee's information is prepared (Table 5, column 2).

\section{ADDITIONAL AND SENSITIVITY ANALYSES}

\section{Effect of enforcement on reducing accounting distance}

Prior studies show that the benefits of adopting new standards like IFRS are largely dependent on their implementation and enforcement (Ball et al. 2003; Holthausen 2009). For example, Daske et al. (2008) find a more pronounced economic benefit to IFRS adoption in countries with strict enforcement. Our empirical tests thus far controlled for country-level enforcement by focusing on the investor mix within an adopting firm. Yet it is possible that the effect of reduced information asymmetry among investors is increasing in the level of enforcement. In this section, we test whether the effect of accounting harmonization differs by country-level enforcement.

We note that because our focus is on the effect of accounting distance, the enforcement tests

serve a slightly different purpose than prior IFRS studies. While prior studies consider the effect of IFRS on an average investor, we focus on how IFRS resolves information asymmetry among investors. This information asymmetry is not only a function of the sound implementation of IFRS but also a function of how investors perceive their information disadvantage relative to other 
investors. While enforcement will directly affect the former, it may have little effect on the latter. The purpose of our enforcement test is to examine these cross-sections.

The enforcement of accounting standards takes various forms in different countries, making it a challenge to find a parsimonious way to measure enforcement levels across countries. We employ two different enforcement measures widely used in prior literature. The first takes into account the strength of a country's law enforcement institutions using the rule of law index (Kaufmann et al. 2003), which is constructed from the Worldwide Governance Indicators and measures the effectiveness of law enforcement in each country. Next, we use the extent of the opportunism exhibited in the reported financials in each country using the country-level earnings management index from Leuz et al. (2003). This index is a composite score of four proxies that capture the level of earnings management based on certain properties of reported earnings. If reported financials exhibit high discretion, we consider the level of enforcement in the country to be low.

We use equation (5) to compare coefficient estimates on $\triangle \mathrm{AD}$ _FIRM $\mathrm{i}_{\mathrm{i}, \mathrm{h}}$ for the high and low enforcement sample via a seemingly unrelated regression (SUR) model. Table 7 reports the results using our aggregate enforcement measure. For parsimony, we examine only the sample from the firm's IFRS adoption. ${ }^{29} \mathrm{We}$ find that the estimated coefficients for high enforcement countries are greater than the estimates shown for low enforcement countries. In Table 7, column 1, we find the effect of accounting harmonization to be statistically significant in countries with strong enforcement $\left(\beta_{1}=-0.089\right)$, but not significant in weak enforcement countries $\left(\beta_{1}=-0.043\right)$. However, the F-tests for both enforcement measures show that the difference is not statistically significant ( $\mathrm{p}$-value $=$ 0.397). In column 2 , we find similar results using the earnings management measure.

\footnotetext{
${ }^{29}$ In untabulated analysis, we find that using the investor's IFRS adoption (as opposed to the firm's IFRS adoption) shows similar results, albeit with reduced statistical significance. This is expected because IFRS adoption on the investor's part changes only the investor's level of familiarity with the new standards. Therefore, enforcement has little role to play.
} 


\section{Sensitivity analysis}

We test the sensitivity of our results to alternative specifications and measures of AD. One assumption underlying our analysis is that the effect of changes in accounting distance is linear, regardless of the resulting $\mathrm{AD}$ level after the adoption. However, it is possible that the changes in AD only manifest themselves when they result in sufficiently low levels of AD in the post period. We thus repeat our analysis using only the sample where the magnitude of accounting distance postIFRS adoption is below the sample median, or $\mathrm{AD}<5$. Table 8 , column 1 shows the estimated results. We find that a decrease in accounting distance matters more when it results in a sufficiently small amount of $\mathrm{AD}$ in the post period.

We examine whether our analysis is robust to an alternative measure of AD. Note that we consider two local accounting standards to be similar if the two countries have the same legal origin. An alternative specification is to consider two local standards to be similar even when the countries have different legal origins, as in the original measures of Bae et al. (2008). In Table 8, column 2, we repeat the analysis in Table 5 using this alternative AD measure. Our inferences remain unchanged.

Next, we examine whether the results are robust to dropping influential observations in the sample. Table 2 shows that the U.K. constitutes 17\% of the firm observations in IFRS adopting countries. We repeat the analysis in Table 5, column 1 after excluding all U.K. firms from the sample. Column 3 in Table 8 shows the estimation. We find that the $\beta_{1}$ coefficient is negative and statistically significant $\left(\beta_{1}=-0.031, \mathrm{t}-\mathrm{stat}=-2.787\right)$. This provides reassurance that our findings are not driven by a single influential country.

We also examine whether the results hold when we exclude an influential country-investor, namely U.S. investors. Khurana and Michas (2011), using country-level aggregate data, show that U.S. investors reduce their underinvestment in countries that adopt IFRS. In addition to U.S. 
investors, our study examines a broad cross-section of investors from 36 different countries. While our broader sample allows us to generalize the findings of Khurana and Michas (2011), we repeat our analysis in Table 5 using only non-U.S. funds to see whether our findings continue to hold for this sub-sample. In column 4 of Table 8, we report our findings using only non-U.S. funds. Consistent with Khurana and Michas (2011), we find that the $\beta_{1}$ coefficient is negative and statistically significant. We believe that our study not only corroborates the findings of Khurana and Michas (2011), it allows us to generalize their findings by directly relating the changes in accounting distance to a broader sample of country-investors.

Finally, we examine the sensitivity of the results using an alternative dependent variable, the $\%$ of ownership, another metric frequently examined in prior literature. As we discuss in section II, the \% ownership held by a certain fund may change not only from changes to the fund's demand, but also from portfolio rebalancing motives when the fund experiences large changes in its own AUM. The measure of over/underweight adjusts for the portfolio rebalancing effect by dividing the \% ownership measure by the fund's relative AUM. If the goal is to separate out the portfolio rebalancing effects, the investment weight will be a better measure than the \% ownership measure. However, if the main interest is to measure a firm's ability to attract foreign investors, the \% ownership is another relevant variable of interest. To examine how important this design choice is for our inferences, we repeat our analysis using the \% ownership measure as the dependent variable.

We repeat our analysis in Table 5, column 1 and find only weak evidence of $\triangle \mathrm{AD}$ affecting the changes in the $\%$ of ownership of different country-investors (not tabulated). While the coefficients on the $\triangle \mathrm{AD}$ variable are negative, they are not statistically significant ( $\mathrm{p}$-value $=0.62$ ). Further examination shows that controlling for the investor's wealth effect, which is one of the advantages of the investment weight measure, indeed improves the statistical significance of the tests. In Table 8 , 
column 5 , we show that the effect of $\triangle \mathrm{AD}$ is significant once we exclude country-funds with annual changes in AUM that are greater or less than 50\% relative to the global market portfolio. The findings highlight the significance of controlling for portfolio rebalancing motives when using the \% of ownership variable. ${ }^{30}$

\section{CONCLUSION}

While capital flows across borders have steadily increased over the past decade, portfolio holdings remain significantly biased toward domestic investments. Information asymmetry has been one explanation for equity home bias, but research has not delved deeply into its nature. This paper examines whether differences in accounting standards affect the portfolio allocation decisions of global investors.

Using the security-level holdings of international mutual funds, we find that differences in accounting standards explain the large variation in the portfolio allocations of mutual fund investors. The effect persists even after controlling for the previously documented determinants of cross-border holdings. Using the global adoption of IFRS as a relatively exogenous event that changed accounting distance across countries, we show that when firms adopted IFRS, they experienced an increase in investment weights. This increase can be particularly attributed to investors who saw the greatest reduction in accounting distance resulting from IFRS adoption. Further, we find that when a fund's country adopts IFRS, the fund similarly responds by allocating greater investment weights to firms that experienced the greatest reduction in accounting distance in the post-adoption period. This

\footnotetext{
${ }^{30}$ In untabulated analyses, we conduct the sensitivity analyses for both the levels analysis (Table 4) and the changes analysis using the $\triangle A D \_F U N D$ variable (Table 6). However, we note that not all sensitivity tests in this section are applicable. For example, the sensitivity test excluding UK firms is less applicable because the main analysis already excludes observations where the investee firm mandatorily adopted IFRS. We nonetheless repeat our analyses for all other applicable sensitivity tests. We find robust results.
} 
suggests that harmonizing accounting standards affects asset allocation decisions by reducing information asymmetry among investors.

Our findings contribute to the literature by showing how differences in accounting standards pose barriers to cross-border investments. Using the mandatory IFRS adoption event, we document the harmonization benefit and also present a measure of accounting harmonization that can be operationalized in future studies. Notwithstanding the importance of these findings, the study is subject to some caveats. First, our analysis is limited to mutual funds. It is possible that mutual funds are more information sensitive than other retail investors and are thus more subject to barriers from accounting standards. However, one can also argue that because mutual funds are a more sophisticated investor group, they would voluntarily overcome such frictions in accounting standards. Second, we focus only on the effect on investor demand. While the findings suggest a change in investor demand, we do not know whether such a change is beneficial for the firm. While increased demand can lead to lower cost of capital, it is possible that the demand can make firms subject to contagion. We leave these interesting avenues of research for future studies. 


\section{References}

Aggarwal, R., L. Klapper, and P. Wysocki, 2005, Portfolio Preferences of Foreign Institutional Investors. Journal of Banking \& Finance 29(12), 2919-2946.

Ahearne, A., W. Griever, and F. Warnock, 2004, Information Costs and Home Bias: An Analysis of US Holdings of Foreign Equities. Journal of International Economics 62, 313-336.

Ammer, J., S. Holland, D. Smith, and F. Warnock, 2005, Look at Me Now: What Attracts U.S. Shareholders. Working paper, Federal Reserve Board of Governors.

Armstrong, C., M. Barth, A. Jagolinzer, and E. Riedl. 2010. Market Reaction to the Adoption of IFRS in Europe. The Accounting Review 85 (1), 31-61.

Bae, K. H., H. Tan, and M. Welker, 2008, International GAAP Differences: The Impact on Foreign Analysts. The Accounting Review 83, 593-628.

Ball, R., A. Robin, and J. Wu, 2003, Incentive versus Standards: Properties of Accounting Income in Four East Asian Countries. Journal of Accounting and Economics 36, 235-270.

Barbieri, K., O. Keshk, and B. Pollins, 2008, Correlates of War Project Trade Data Set Codebook, Version 2.01. Online: http://correlatesofwar.org.

Barth, M., G. Clinch, and T. Shibano, 1999, International Accounting Harmonization and Global Equity Markets. Journal of Accounting and Economics 26, 201-235.

Barth, M., W. Landsman, and M. Lang, 2008, International Accounting Standards and Accounting Quality. Journal of Accounting Research 46, 467-498.

Beneish, M. D., B. P. Miller, and T. L. Yohn, 2012, The Impact of Financial Reporting on Equity versus Debt Markets: Macroeconomic Evidence from Mandatory IFRS Adoption. Working paper.

Bradshaw, M., B. Bushee, and G. Miller, 2004, Accounting Choice, Home Bias and US Investment in NonUS Firms. Journal of Accounting Research 42, 795-841.

Bradshaw, M., and G. Miller, 2007, Will Harmonizing Accounting Standards Really Harmonize Accounting? Evidence from Non-U.S. Firms Adopting US GAAP. Journal of Accounting, Auditing and Finance 23(2), 1 40 .

Chan, K., V. Covrig, and L. Ng, 2005, What Determines the Domestic Bias and Foreign Bias? Evidence from Mutual Fund Equity Allocations Worldwide. Journal of Finance 3, 1495-1533.

Chen, F., O-K. Hope, Q. Li, and X. Wang, 2013, Earnings Opacity and Closed-End Fund Discounts, Working paper.

Comprix, J., K. Muller III, and M. Stanford, 2003, Economic Consequences from Mandatory Adoption of IASB Standards in the European Union. Working paper, Pennsylvania State University.

Covrig, V., M. DeFond, and M. Hung, 2007, Home Bias, Foreign Mutual Fund Holdings, and the Voluntary Adoption of International Accounting Standards. Journal of Accounting Research 45, 41-70.

Daske, H., L. Hail, C. Leuz, and R. Verdi, 2008, Mandatory IFRS Reporting Around the World: Early Evidence on the Economic Consequences. Journal of Accounting Research 46(5), 1085-1142.

Daske, H., L. Hail, C. Leuz, and R. Verdi. 2013, Adopting a Label: Heterogeneity in the Economic Consequences of IFRS Adoptions. Journal of Accounting Research 51(3), 495-547. 
De Franco, G., S. Kothari, and R. Verdi, 2011, The Benefits of Financial Statement Comparability. Journal of Accounting Research 49, 895-931.

DeFond, M., X. Hu, M. Hung, and S. Li., 2011, The Impact of Mandatory IFRS Adoption on Foreign Mutual Fund Ownership: The Role of Comparability. Journal of Accounting and Economics 51(3), 240-258.

Diamond, W., and R. Verrecchia, 1991, Disclosure, Liquidity, and the Cost of Capital. Journal of Finance 46, 1325-1359.

Ding, Y., O-K. Hope, T. Jeanjean, and H. Stolowy. 2007, Differences between Domestic Accounting Standards and IAS: Measurement, Determinants and Implications. Journal of Accounting and Public Policy $26(1), 1-38$.

Florou, A., and P. Pope, 2012, Mandatory IFRS Adoption and Institutional Investment Decisions. The Accounting Review 87(6), 1993-2025.

GAAP, 2001, A Survey of National Accounting Rules Benchmarked Against International Accounting Standards (IFAD 2001).

Gehrig, T., 1998, Cities and the Geography of Financial Centers. CEPR Discussion Papers 1894.

Gelos, G., and G. Wei, 2005, Transparency and International Portfolio Holdings. Journal of Finance 60, 2987-3020.

Grauer, F. L. A., R. H. Litzenberger, and R. E. Stehle, 1976, Sharing Rules and Equilibrium in an International Market under Uncertainty. Journal of Financial Economics 3, 233-256.

Harris, T., 1998, Overcoming Accounting Differences. A Stockpicker's Guide to the Numbers that Count. Morgan Stanley Dean Witter Apples to Apples project.

Hau, H., and H. Rey, 2008, Home Bias at the Fund Level. American Economic Review 98, 333-338.

Hawkins, D., 2001, International Accounting Standards: Updated Review, Handling Diversity and U.S. GAAP Contrasted. Accounting Bulletin 99.

Holthausen, R., 2009, Accounting Standards, Financial Reporting Outcomes, and Enforcement. Journal of Accounting Research 47(2), 447-458.

Hung, M., 2001, Accounting Standards and Value Relevance of Financial Statements: An International Analysis. Journal of Accounting and Economics 30, 401-420.

Kang, J. K., and R. Stulz, 1997, Why Is There a Home Bias? An Analysis of Foreign Portfolio Equity Ownership in Japan. Journal of Financial Economics 46(1), 3-28.

Karolyi, A., and R. Stulz, 2003, Are Financial Assets Priced Locally or Globally? In Handbook of the Economics of Finance, Vol. 1(B), Edited by G.M. Constantinides, M. Harris and R.M. Stulz, 975-1020. Amsterdam: Elsevier.

Kaufmann, D., A. Kraay, and M. Mastruzzi, 2003, Governance Matters III: Governance Indicators for 19962002. Working paper, World Bank Policy Research \#3106.

Kho, B-C, R. Stulz, and F. Warnock, 2009, Financial Globalization, Governance, and the Evolution of the Home Bias. Journal of Accounting Research 47(2), 597-635. 
Khurana, I. K., and P. N. Michas, 2011, Mandatory IFRS Adoption and the U.S. Home Bias. Accounting Horizons 25(4), 729-753.

Landsman, W. R., E. L. Maydew, and J. R. Thornock, 2012, The Information Content of Annual Earnings Announcements and Mandatory Adoption of IFRS. Journal of Accounting and Economics 53, 34-54.

Leuz, C., K. Lins, and F. Warnock, 2010, Do Foreigners Invest Less in Poorly Governed Firms? Review of Financial Studies 23(3), 3245-3285.

Leuz, C., D. Nanda, and P. Wysocki, 2003, Earnings Management and Investor Protection: An International Comparison. Journal of Financial Economics 69, 505-527.

Lewis, K., 1999, Trying to Explain Home Bias in Equities and Consumption. Journal of Economic Literature 37, 571-608.

Louis, H., and O. Urcan, 2012, The Effect of IFRS on Cross-Border Acquisitions. Working paper.

Nobes, C., 2002, GAAP 2001-A Survey of National Accounting Rules Benchmarked against International Accounting Standards by Andersen, BDO, Deloitte Touche Tohamtsu, Ernst \& Young, Grant Thornton, KPMG, and PricewaterhouseCoopers. New York: J. Wiley \& Sons.

Obstfeld, M., and K. Rogoff, 2001, The Six Major Puzzles in International Macroeconomics: Is There a Common Cause? 2000 NBER Macroeconomics Annual. Cambridge, MA: MIT Press.

Portes, R., and H. Rey, 2005, The Determinants of Cross-border Equity Flows. Journal of International Economics 65, 269-296.

PricewaterhouseCoopers, 2007, IFRS for SMEs Pocket Guide 2007.

Ramanna, K. and E. Sletten, 2014, Network effects in countries' adoption of IFRS. The Accounting Review, In-Press.

Reinhart, C., and K. Rogoff, 2003, The Modern History of Exchange Rate Arrangements: A Reinterpretation. Working paper, International Monetary Fund.

Salter, S. B., and T.S. Doupnik, 1992, The Relationship between Legal Systems and Accounting Practices. Advances in International Accounting 5, 3-22.

Seidler, L.J., 1967. International Accounting- The Ultimate Theory Course. The Accounting Review 42, 775 781.

Shroff, N., R.S. Verdi, and G. Yu, 2013 Information Environment and the Investment Decisions of Multinational Corporations. The Accounting Review, In-Press.

Van Nieuwerburgh, S., and L. Veldkamp, 2009, Information Immobility and the Home Bias Puzzle. Journal of Finance 64, 1187-1215.

Yu, G., 2010, Bridging the GAAPs 2012. Harvard Business School Case 111-114. 
Appendix A: Measure of firm i's over/underweight in the portfolio of investors from country $h$

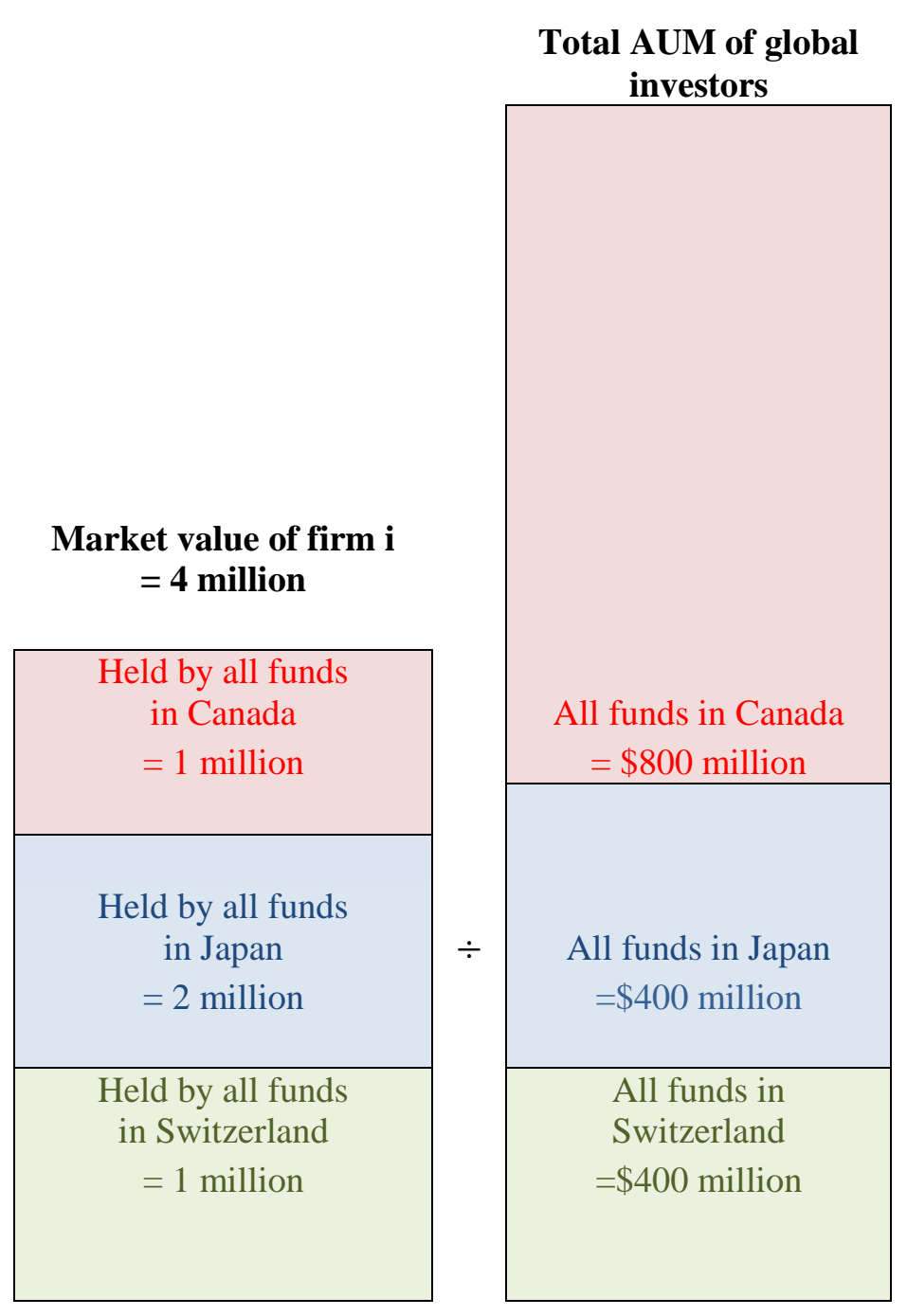

Market value of global portfolio $=1,600$ million

\section{Weight of firm i in \\ country $h$ investor's portfolio}

$\left(=\mathbf{w}_{\mathrm{i}, \mathrm{h}}\right)$

weight $_{\mathrm{i}, \text { Canada }}=1 / 800$

weight $_{i, \text { Japan }}=2 / 400$

weight $_{\mathrm{i} \text {, Switzerland }}=1 / 400$
Over/underweight of firm $i$ in country $h$ investor's portfolio

$\left(\right.$ Weight $\left._{\mathrm{i}, \mathrm{h}}=\mathbf{w}_{\mathrm{i}, \mathrm{h}} / \mathbf{w}_{\mathbf{i}}{ }^{*}\right)$

over/underweight $_{\mathrm{i} \text {, Canada }}=0.5$

over/underweight $_{\mathrm{i} \text {, Japan }}=2$

over/underweight $_{\mathrm{i} \text {, Switzerland }}=1$

Weight of firm i as a \% of global market portfolio $\left(=w_{i}^{*}\right)$

$=4$ million $/ 1,600$ million $=1 / 400$ 


\section{Appendix B.1: Measures of local accounting distance for each country-pair}

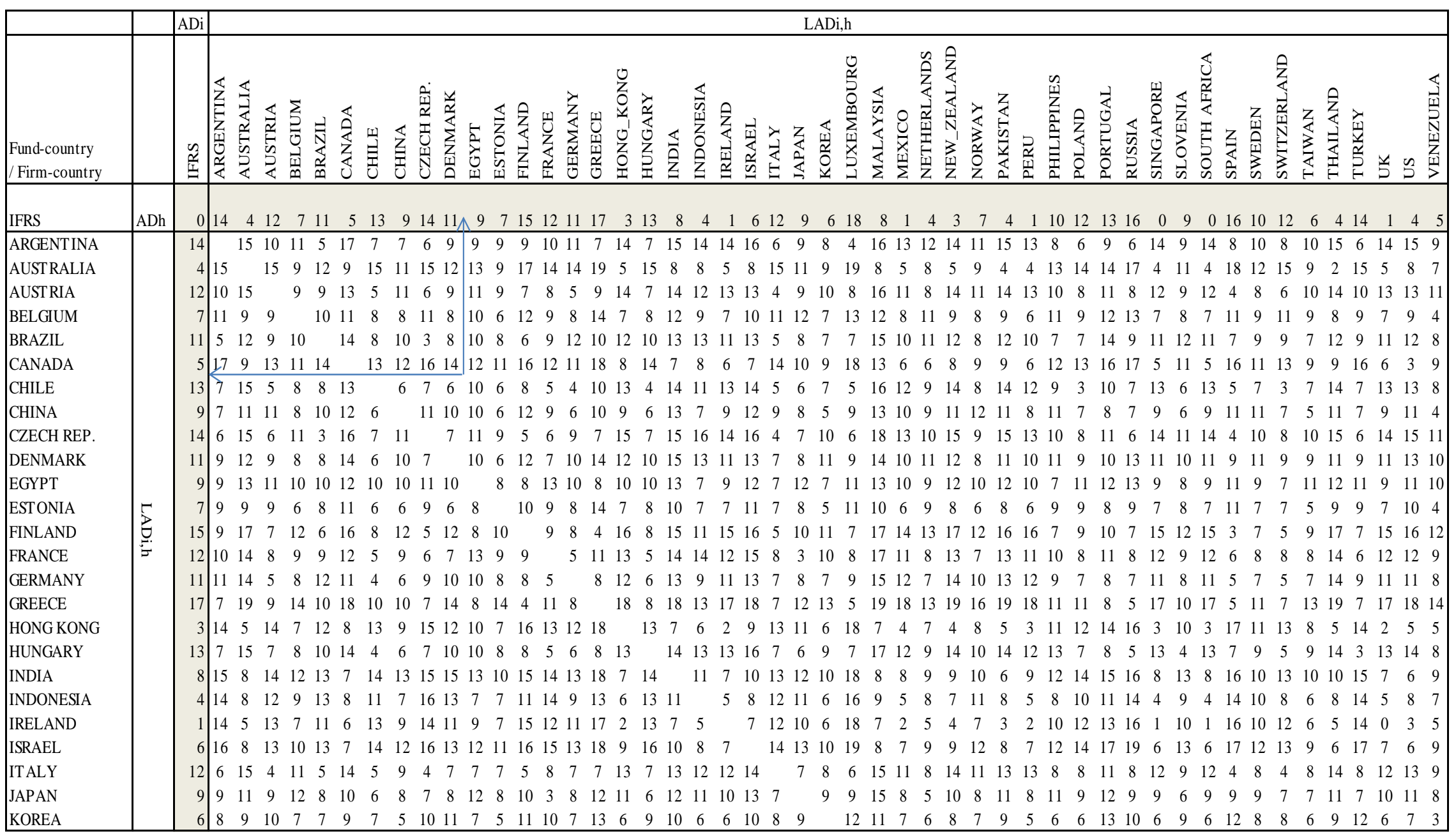

Notes: $\mathrm{LAD}_{\mathrm{i}, \mathrm{h}}$ : The distance between the local accounting standards used by firm $\mathrm{i}$ and the local accounting standards used in country h, where the fund is domiciled. $\mathrm{AD}_{\mathrm{h}}$ : The distance between the local accounting standards used in country $\mathrm{h}$, where the fund is domiciled, and IFRS. $\mathrm{AD}_{\mathrm{i}}$ : The distance between the local accounting standards used by firm $i$ and IFRS. 


\section{Appendix B.1: Measures of local accounting distance for each country-pair (Continued)}

\begin{tabular}{|c|c|c|c|c|c|c|c|c|c|c|c|c|c|c|c|c|c|c|c|c|c|c|c|c|c|c|c|c|c|c|c|c|c|c|c|c|c|c|c|c|c|c|c|c|c|c|c|c|c|}
\hline & & Di & \multicolumn{47}{|c|}{ LADi,h } \\
\hline $\begin{array}{l}\text { Fund-c } \\
\text { Firm- }\end{array}$ & & $\begin{array}{l}\underline{y} \\
\underline{I} \\
\end{array}$ & & 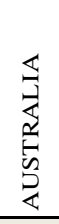 & 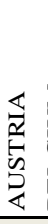 & & 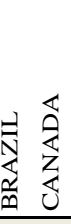 & & & & & & 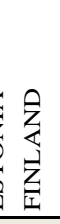 & & & & & & & & & & & & & & & 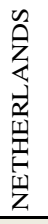 & & & 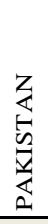 & & $\begin{array}{l}\bar{a} \\
\underline{a} \\
\underline{a} \\
\underline{a}\end{array}$ & $\begin{array}{l}\mathrm{Z} \\
\mathrm{Z} \\
\mathrm{Z} \\
\mathrm{L}\end{array}$ & & & & & $\begin{array}{l}\vec{b} \\
\overrightarrow{3} \\
\vec{n} \\
\end{array}$ & & & & & & & & & & 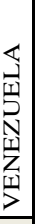 \\
\hline FRS & & 0 & 14 & $\begin{array}{r}4 \quad 4 \\
\end{array}$ & 12 & 71 & $\begin{array}{ll}11 \quad 5 \\
\end{array}$ & 13 & 9 & 14 & 11 & $\begin{array}{ll}9 & 7 \\
\end{array}$ & 715 & 12 & 11 & 17 & & 13 & 8 & 4 & 1 & 61 & 2 & $\begin{array}{ll}9 & 6 \\
\end{array}$ & 18 & 8 & 1 & 4 & 3 & 7 & 4 & 1 & 10 & 12 & 21 & 31 & & 0 & 9 & 01 & 161 & 10 & 12 & 6 & 41 & $14 \quad 1$ & 1 & & 5 \\
\hline UXE & & 18 & 4 & 19 & 8 & 13 & $\begin{array}{ll}7 & 18\end{array}$ & 5 & 9 & 6 & 91 & 1111 & 17 & 8 & 9 & 5 & 18 & 7 & 18 & 16 & 181 & 19 & 69 & 7 12 & & 20 & 17 & 14 & 18 & 11 & 19 & 17 & 10 & 6 & & & & 8 & $\begin{array}{ll}9 & 1\end{array}$ & 18 & 4 & 10 & 8 & & & $\begin{array}{ll}6 & 18\end{array}$ & $8 \quad 18$ & & 13 \\
\hline MAL & & 8 & 16 & 8 & 16 & 121 & 1513 & 16 & 13 & 18 & 141 & 1310 & 017 & 17 & 15 & 19 & 7 & 17 & 8 & 9 & 7 & $\begin{array}{ll}8 & 1\end{array}$ & $\begin{array}{ll}515 \\
5\end{array}$ & $\begin{array}{lll}511 \\
\end{array}$ & 20 & & 8 & 12 & 7 & 13 & 4 & 9 & 13 & 16 & 614 & & & 8 & 15 & 81 & 191 & 13 & 141 & 10 & $\begin{array}{ll}8 & 1\end{array}$ & 187 & 7 & $\begin{array}{lll}10 & 11\end{array}$ & 10 \\
\hline MEXI & & 1 & 13 & 5 & 11 & 81 & 106 & 12 & 10 & 13 & 101 & 106 & 14 & 11 & 12 & 18 & 4 & 12 & 8 & 5 & 2 & $\begin{array}{ll}71 \\
\end{array}$ & 18 & 37 & 17 & 8 & & 5 & 3 & 6 & 4 & 2 & 9 & 11 & 112 & & & 1 & 10 & 11 & 15 & 9 & 11 & & & 132 & 2 & 6 & \\
\hline JETI & & 4 & 12 & 8 & 8 & 111 & 116 & 9 & 9 & 10 & 11 & 99 & 13 & 8 & 7 & 13 & 7 & 9 & 9 & 8 & 5 & 98 & $8 \quad 5$ & 56 & 14 & 12 & 5 & & 7 & 7 & 8 & 5 & 10 & 10 & $\begin{array}{lll}0 & 13\end{array}$ & & & 4 & 7 & 41 & 128 & 8 & 8 & & $\begin{array}{ll}8 & 1\end{array}$ & 125 & 5 & 7 & 7 \\
\hline NEW & & 3 & 14 & 45 & 14 & 9 & 128 & 14 & 11 & 15 & 121 & 128 & 17 & 13 & 14 & 19 & 4 & 14 & 9 & 7 & 4 & $\begin{array}{ll}9 & 1\end{array}$ & 410 & $\begin{array}{ll}0 & 8\end{array}$ & 18 & 7 & 3 & 7 & & 8 & 5 & 3 & 12 & 13 & $\begin{array}{ll}3 & 14\end{array}$ & & & 3 & 11 & 3 & 181 & 12 & 14 & & & 154 & 4 & 7 & \\
\hline NORW & & 7 & 11 & 19 & 11 & 8 & $\begin{array}{ll}8 & 9\end{array}$ & 8 & 12 & 9 & $\begin{array}{ll}8 & 1\end{array}$ & 106 & 12 & 7 & 10 & 16 & 8 & 10 & 10 & 11 & 71 & 121 & 18 & 37 & 11 & 13 & 6 & 7 & 8 & & 9 & 6 & 7 & 7 & 12 & 1 & & 7 & 10 & 71 & 11 & 5 & 11 & & & 117 & 7 & 8 & \\
\hline AKIS & & 4 & 15 & 54 & 14 & 9 & 129 & 14 & 11 & 15 & 111 & 128 & 16 & 13 & 13 & 19 & 5 & 14 & 6 & 8 & 3 & $\begin{array}{ll}8 & 1\end{array}$ & $\begin{array}{ll}311 \\
3\end{array}$ & 19 & 19 & 4 & 4 & 8 & 5 & 9 & & 5 & 12 & 14 & 413 & & & 4 & 12 & 41 & 171 & 11 & 13 & & & 153 & 3 & 6 & \\
\hline ERU & & 1 & 13 & 34 & 13 & 61 & 106 & 12 & 8 & 13 & & 106 & 16 & 11 & 12 & 18 & 3 & 12 & 9 & 5 & 2 & $7 \quad 1$ & $\begin{array}{ll}38 \\
\end{array}$ & 5 & 17 & 9 & 2 & 5 & 3 & 6 & 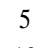 & & 11 & 11 & 1 & & & 1 & 8 & 11 & 171 & 11 & 13 & 7 & $\begin{array}{ll}4 & 1\end{array}$ & 132 & 2 & 4 & 4 \\
\hline HILI & & 10 & 8 & 13 & 10 & 11 & $\begin{array}{ll}7 \quad 12 \\
\end{array}$ & 9 & 11 & 10 & & 79 & 7 & 10 & 9 & 11 & 11 & 13 & 12 & 8 & 101 & 128 & $\begin{array}{ll}8 & 11\end{array}$ & 16 & 10 & 13 & 9 & 10 & 12 & 7 & 12 & 11 & & 6 & 13 & & & 0 & 151 & 10 & 8 & 4 & 8 & & & 1210 & $\begin{array}{lll}0 & 10\end{array}$ & 10 & 9 \\
\hline OLA & & 12 & 6 & 14 & 8 & 9 & $\begin{array}{ll}7 & 13\end{array}$ & 3 & 7 & 8 & 91 & 119 & 9 & 8 & 7 & 11 & 12 & 7 & 14 & 10 & 121 & 148 & 89 & 6 & 6 & 16 & 11 & 10 & 13 & 7 & 14 & 11 & 6 & & 11 & & & 2 & 91 & 12 & 6 & 8 & 6 & & & $\begin{array}{ll}8 \quad 12\end{array}$ & & & 9 \\
\hline ORT & & 13 & 9 & 14 & 11 & 121 & 1416 & 10 & 8 & 11 & 101 & 128 & 10 & 11 & 8 & 8 & 14 & 8 & 15 & 11 & 131 & 171 & 112 & 213 & 9 & 14 & 12 & 13 & 14 & 12 & 13 & 14 & 13 & 11 & & & & 3 & 101 & 13 & 9 & 11 & 9 & 1 & 15 & $\begin{array}{ll}7 \quad 13 \\
\end{array}$ & 3 & 161 & \\
\hline RUSSI & & 16 & 6 & 17 & 8 & 13 & $\begin{array}{ll}9 & 17\end{array}$ & 7 & 7 & 6 & 131 & 139 & 7 & 8 & 7 & 5 & & 5 & 16 & 14 & 161 & 198 & 89 & 9 10 & 4 & 18 & 15 & 12 & 16 & 11 & 17 & 15 & 12 & & & & & & $\begin{array}{ll}9 & 1\end{array}$ & 16 & 6 & 10 & 8 & 101 & & $\begin{array}{ll}6 & 16\end{array}$ & $\begin{array}{ll}6 & 17\end{array}$ & & 11 \\
\hline INGA & هِg & 0 & 14 & 44 & 12 & 71 & 115 & 13 & 9 & 14 & 11 & $\begin{array}{ll}9 & 7\end{array}$ & 15 & 12 & 11 & 17 & 3 & 13 & 8 & 4 & 1 & $\begin{array}{ll}6 & 1\end{array}$ & 29 & 96 & 18 & 8 & 1 & 4 & 3 & 7 & 4 & 1 & 10 & 12 & $\begin{array}{lll}2 & 1\end{array}$ & 31 & 0 & & 9 & 0 & 161 & 10 & 12 & 64 & $\begin{array}{ll}4 & 1\end{array}$ & 141 & 14 & 45 & 5 \\
\hline $\mathrm{LOV}$ & & 9 & 9 & 11 & 9 & 81 & 1211 & 6 & 6 & 11 & 10 & 8 & 12 & 9 & 8 & 10 & 10 & 4 & 13 & 9 & 101 & 13 & 96 & $5 \quad 9$ & 9 & 15 & 10 & 7 & 11 & 10 & 12 & 8 & 15 & 9 & 1 & & & 9 & & 91 & 11 & 11 & 7 & & 107 & $\begin{array}{ll}7 \quad 10\end{array}$ & $\begin{array}{ll}0 & 12\end{array}$ & 128 & 8 \\
\hline SOUT & & 0 & 14 & 44 & 12 & 71 & 115 & 13 & 9 & 14 & 11 & $\begin{array}{ll}9 & 7\end{array}$ & 15 & 12 & 11 & 17 & & 13 & 8 & 4 & 1 & $\begin{array}{ll}6 & 1\end{array}$ & 29 & 6 & 18 & 8 & 1 & 4 & 3 & 7 & 4 & 1 & 10 & 12 & $\begin{array}{ll}2 & 1\end{array}$ & & & 0 & 9 & & 161 & 10 & 12 & 64 & 4 & 141 & & 45 & 5 \\
\hline PAI & & 16 & 8 & 18 & 4 & 11 & $7 \quad 16$ & 5 & 11 & 4 & 91 & 1111 & 13 & 6 & 5 & 5 & & 7 & 16 & 14 & 161 & 17 & 49 & ) 12 & 4 & 19 & 15 & 12 & 18 & 11 & 17 & 17 & 8 & 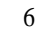 & & & & 6 & 11 & 16 & & & 6 & 101 & 18 & $\begin{array}{ll}6 & 16\end{array}$ & 6 & 161 & 13 \\
\hline WE & & 10 & 10 & 12 & 8 & 9 & $\begin{array}{ll}9 & 11\end{array}$ & 7 & 11 & 10 & 11 & $\begin{array}{ll}9 & 7\end{array}$ & 7 & 8 & 7 & 11 & 11 & 9 & 10 & 10 & 101 & 128 & 9 & 8 & 10 & 13 & 9 & 8 & 12 & 5 & 11 & 11 & 4 & 8 & 1 & & & 0 & 11 & 10 & 8 & & 6 & 1 & 131 & 1010 & $\begin{array}{lll}0 & 10\end{array}$ & 107 & 7 \\
\hline WIT & & 12 & 8 & 15 & 6 & 11 & $\begin{array}{ll}9 & 13\end{array}$ & 3 & 7 & 8 & 9 & 77 & 5 & 8 & 5 & 7 & 13 & 5 & 13 & 8 & 121 & 13 & 7 & 8 & 8 & 14 & 11 & 8 & 14 & 11 & 13 & 13 & 8 & 6 & 5 & & & 2 & 7 & & 6 & 6 & & $\begin{array}{ll}6 & 1\end{array}$ & 14 & $\begin{array}{ll}8 & 12\end{array}$ & $\begin{array}{ll}213 \\
\end{array}$ & 139 & 9 \\
\hline AII & & 6 & 10 & 9 & 10 & 9 & 79 & 7 & 5 & 10 & 91 & 115 & 9 & 8 & 7 & 13 & 8 & 9 & 10 & 6 & 6 & 98 & 8 & 6 & 12 & 10 & 5 & 8 & 8 & 9 & 7 & 7 & 8 & 8 & 3 & & & 6 & 11 & 6 & 10 & 8 & 6 & & & 106 & $\begin{array}{ll}6 & 8\end{array}$ & 8 & 5 \\
\hline & & 4 & 15 & 52 & 14 & 8 & 129 & 14 & 11 & 15 & & 129 & 17 & 14 & & 19 & 5 & 14 & 10 & 8 & 5 & $\begin{array}{ll}6 & 1\end{array}$ & 411 & 19 & 19 & 8 & 5 & 8 & 5 & 10 & 4 & 4 & 14 & . 14 & 41 & & & 4 & 10 & 4 & 181 & 13 & 14 & 9 & & $15 \quad 5$ & 8 & 8 & 7 \\
\hline URK & & 14 & 6 & 15 & 10 & 9 & 916 & 7 & 7 & 6 & 91 & 119 & 7 & 6 & 9 & 7 & 14 & 3 & 15 & 14 & 141 & 178 & 87 & 712 & 6 & 18 & 13 & 12 & 15 & 11 & 15 & 13 & 12 & 8 & 7 & & & 4 & 7 & 14 & $\begin{array}{ll}6 & 1\end{array}$ & 10 & 8 & & 15 & 14 & 410 & 169 & 9 \\
\hline JK & & 1 & 14 & 45 & 13 & 71 & 116 & 13 & 9 & 14 & 11 & $\begin{array}{ll}9 & 7\end{array}$ & 15 & 12 & 11 & 17 & 2 & 13 & 7 & 5 & 0 & $\begin{array}{ll}71 \\
\end{array}$ & 210 & $\begin{array}{ll}0 & 6\end{array}$ & 18 & 7 & 2 & 5 & 4 & 7 & 3 & 2 & 10 & 12 & $\begin{array}{ll}2 & 1\end{array}$ & & & 1 & 10 & 11 & 161 & 10 & 12 & 6 & $\begin{array}{ll}5 & 1\end{array}$ & 14 & & 3 & \\
\hline J.S. & & 4 & 15 & 58 & 13 & 9 & 123 & 13 & 11 & 15 & 131 & 1110 & 016 & 12 & 11 & 18 & 5 & 14 & 6 & 8 & 3 & $\begin{array}{ll}6 & 1\end{array}$ & $\begin{array}{lll}3 & 11\end{array}$ & 17 & 18 & 10 & 5 & 6 & 7 & 8 & 6 & 5 & 10 & 12 & 21 & & & 4 & 12 & 4 & 161 & 10 & 13 & 8 & $\begin{array}{ll}8 & 1\end{array}$ & 163 & 3 & & 7 \\
\hline IENEZUELA & & 5 & 9 & 7 & 11 & 4 & $8 \quad 9$ & 8 & 4 & 11 & & $\begin{array}{ll}10 \quad 4 \\
\end{array}$ & 12 & 9 & 8 & 14 & & 8 & 9 & & 5 & 9 & $\begin{array}{l}9 \quad 8 \\
\end{array}$ & 3 & 13 & 10 & 6 & 7 & 7 & 8 & 7 & 4 & & & 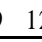 & & & & & 5 & 13 & 7 & 9 & 5 & & $\begin{array}{ll}9 \quad 5 \\
\end{array}$ & 5 & 7 & \\
\hline
\end{tabular}

Notes: LAD $_{\mathrm{i}, \mathrm{h}}$ : The distance between the local accounting standards used by firm $\mathrm{i}$ and the local accounting standards used in country h, where the fund is

domiciled. $\mathrm{AD}_{\mathrm{h}}$ : The distance between the local accounting standards used in country $\mathrm{h}$, where the fund is domiciled, and IFRS. $\mathrm{AD}_{\mathrm{i}}$ : The distance between the local accounting standards used by firm i and IFRS. 


\section{Appendix B.2: Definition of changes in accounting distance from IFRS adoption}

Definitions:

$\mathrm{LAD}_{\mathrm{i}, \mathrm{h}}$ : The distance between the local accounting standards used by investee firm $\mathrm{i}$ and the local accounting standards used in country $\mathrm{h}$, where the fund is domiciled.

$\mathrm{AD}_{\mathrm{h}}$ : The distance between the local accounting standards used in country h, where the fund is domiciled, and IFRS.

$\mathrm{AD}_{\mathrm{i}}$ : The distance between the local accounting standards used by the investee firm $\mathrm{i}$ and IFRS.

\section{Case I: Changes from the investee's (i.e., firm's) IFRS adoption}
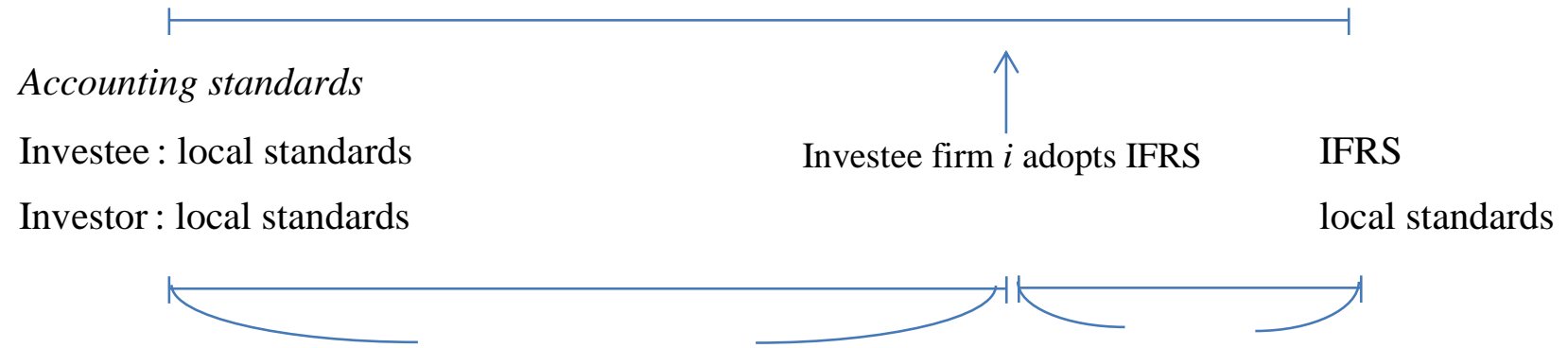

Accounting distance $\quad \mathrm{AD}_{\text {pre }}=\mathrm{LAD}_{\mathrm{i}, \mathrm{h}} \quad \mathrm{AD}_{\text {post }}=\mathrm{AD}_{\mathrm{h}}$

$\Delta \mathrm{AD} \_\mathrm{FIRM}_{\mathrm{i}, \mathrm{h}}=\mathrm{AD}_{\text {post }}-\mathrm{AD}_{\text {pre }}=\mathbf{A D}_{\mathbf{h}}-\mathbf{L A D}_{\mathbf{i}, \mathbf{h}}$

Case II: Changes from the investor's (i.e., fund) IFRS adoption

Accounting standards

Investee: local standards

Investor: local standards

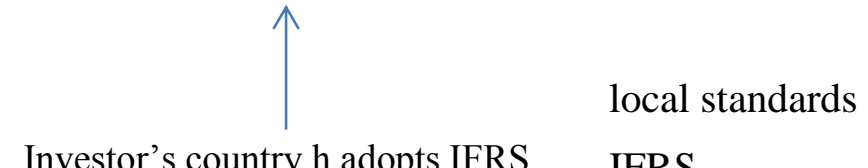

Investor's country h adopts IFRS IFRS

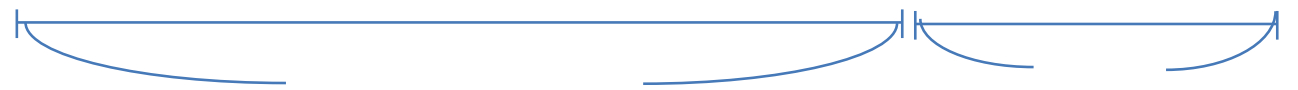

Accounting distance $\quad \mathrm{AD}_{\text {pre }}=\mathrm{LAD}_{\mathrm{i}, \mathrm{h}} \quad \mathrm{AD}_{\text {post }}=\mathrm{AD}_{\mathrm{i}}$

$\Delta \mathrm{AD}_{-} \mathrm{FUND}_{\mathrm{i}, \mathrm{h}}=\mathrm{AD}_{\text {post }}-\mathrm{AD}_{\text {pre }}=\mathbf{A D}_{\mathbf{i}}-\mathbf{L A D}_{\mathbf{i}, \mathbf{h}}$ 
Appendix C: Determinants of cross-border investments

\begin{tabular}{|c|c|c|c|c|}
\hline Variable & Name & Measure & Definition & Source \\
\hline \multicolumn{5}{|c|}{ Country-pair-level determinants } \\
\hline $\begin{array}{l}\text { Accounting } \\
\text { distance }\end{array}$ & $\mathrm{LAD}_{\mathrm{i}, \mathrm{h}}$ & $\sum_{\mathrm{s}=1}^{21} \mathrm{LAD}_{\mathrm{i}, \mathrm{h}, \mathrm{s}}$ & \multicolumn{2}{|c|}{$\begin{array}{l}\text { Differences in the local accounting standards between the country of firm } \mathrm{i} \text { and the Bae et al. }(2008 \text {, Table } 1) \\
\text { country of investing fund } \mathrm{h} \text { based on a survey examining the extent to which local and authors' calculations } \\
\text { accounting standards deviate from IFRS for a list of } 21 \text { accounting rules (GAAP } \\
\text { 2001). Two countries' rules are considered similar }\left(\mathrm{LAD}_{\mathrm{i}, \mathrm{h}, \mathrm{s}}=0\right) \text { when both comply } \\
\text { with IFRS. Two countries following local standards that do not comply with IFRS } \\
\text { are considered to have similar rules only if they derive from the same legal origin. A } \\
\text { higher score implies a greater difference. }\end{array}$} \\
\hline \multirow{3}{*}{$\begin{array}{l}\text { Cost of private } \\
\text { information } \\
\text { acquisition }\end{array}$} & Geographic distance & $I_{i, h}$ & \multicolumn{2}{|c|}{$\begin{array}{l}\text { An indicator that takes a value of one if the countries where the firm and the fund are Portes and Rey (2005) } \\
\text { incorporated do not share a common border, and zero otherwise. }\end{array}$} \\
\hline & Net trade & $\log \left(\mathrm{NX}_{\mathrm{i}, \mathrm{h}}+\mathrm{NX} \mathrm{X}_{\mathrm{h}, \mathrm{i}}\right)$ & \multicolumn{2}{|c|}{$\begin{array}{l}\text { Total net exports between firm i's country and the fund's country h during year t (in Barbieri, Keshk, and } \\
\text { billions of U.S. dollars). }\end{array}$} \\
\hline & Language distance & Distance $_{\mathrm{i}, \mathrm{h}}$ & \multicolumn{2}{|c|}{$\begin{array}{l}\text { Differences in the language used in the countries where firm and fund are Portes and Rey (2005) } \\
\text { incorporated, as designed by Lewis (2009). The distance is measured based on a } \\
\text { classification system that groups languages together by families and up to three levels } \\
\text { of branches and sub-branches within each family. If two languages are from different } \\
\text { families, the measure takes a value of } 4 \text {. If the two are from the same family but } \\
\text { different branches, the value is } 3 ; 2 \text { if they are from the same branch but are different } \\
\text { at the first sub-branch level; } 1 \text { if they are from the same sub-branch at the first level } \\
\text { but are different at the second level; and } 0 \text { if the two are the same language. }\end{array}$} \\
\hline \multicolumn{5}{|c|}{ Country-level determinants } \\
\hline & \# of listed companies & $\#$ of firm ${ }_{i, t}$ & $\begin{array}{l}\text { Number of domestically incorporated companies listed on the country's stock } \\
\text { exchanges at the end of the year, not including investment companies, mutual funds, } \\
\text { or other collective investment vehicles. }\end{array}$ & $\begin{array}{l}\text { S\&P, Global Stock } \\
\text { Markets Factbook }\end{array}$ \\
\hline & FDI flows & $\mathrm{FDI}_{\mathrm{i}}$ & $\begin{array}{l}\text { Net inflows of investment acquiring a management interest ( } 10 \% \text { or more of voting } \\
\text { stock) in an enterprise operating in a country. Calculated as the sum of equity capital, } \\
\text { reinvestment of earnings, other long-term capital, and short term capital, as shown in } \\
\text { the balance of payments. }\end{array}$ & $\begin{array}{l}\text { IMF, International } \\
\text { Financial Statistics and } \\
\text { Balance of Payments } \\
\text { database }\end{array}$ \\
\hline & Index returns & $\operatorname{Ret}_{i, t}$ & $\begin{array}{l}\text { Annual market return of the equity index in country } i \text {, zero if the country does not } \\
\text { have a local stock exchange. }\end{array}$ & $\begin{array}{l}\text { The World Bank, World } \\
\text { Development Indicator } \\
\text { (WDI) }\end{array}$ \\
\hline & GDP growth & $\% \Delta \mathrm{GDP}_{\mathrm{i}, \mathrm{t}}$ & \multirow{2}{*}{\multicolumn{2}{|c|}{$\begin{array}{l}\text { Annual percentage growth rate of GDP in country i at market prices based on constant The World Bank, WDI } \\
\text { local currency. } \\
\text { Gross domestic product (in U.S. dollars) divided by the midyear population of firm i's The World Bank, WDI } \\
\text { country. }\end{array}$}} \\
\hline & GDP per capita & $\begin{array}{l}\mathrm{GDP}_{\mathrm{i}, \mathrm{t}} \\
\text { / population } \\
\mathrm{i}, \mathrm{t}\end{array}$ & & \\
\hline
\end{tabular}


Appendix C: Determinants of cross-border investments (Continued)

\begin{tabular}{|c|c|c|c|c|}
\hline Variable & Var name & Measure & Definition & Source \\
\hline & Turnover & $\mathrm{Vol}_{\mathrm{i}, \mathrm{t}} / \mathrm{GDP}_{\mathrm{i}, \mathrm{t}}$ & Total annual value of shares traded on the local stock exchange scaled by GDP. & The World Bank, WDI \\
\hline & Annual inflation & INF_rate $_{i, t}$ & Inflation as measured by the consumer price index using the Laspeyres formula. & The World Bank, WDI \\
\hline & Real exchange rate & $\mathrm{EX}_{-}$rate $\mathrm{i}, \mathrm{t}$ & $\begin{array}{l}\text { The country's nominal effective exchange rate relative to USD expressed in foreign } \\
\text { currency per USD dollar, divided by a price deflator (or an index of costs). }\end{array}$ & The World Bank, WDI \\
\hline \multicolumn{5}{|c|}{ Firm-level determinants } \\
\hline & \multicolumn{2}{|l|}{ Comparability } & $\begin{array}{l}\text { The \# of peer firms in the same country-industry-year using the same local accounting } \\
\text { standards. Industry classification is based on the industry variable in Worldscope. }\end{array}$ & DeFond et al. (2011) \\
\hline & $\Delta$ Comparability & $\begin{array}{l}\text { \# firms } \\
\text { /\#RSS, post_- } \\
\text { /\#irms } \\
\text { local,pre }\end{array}$ & $\begin{array}{l}\text { A ratio, calculated as the \# of peer firms in the same country-industry using IFRS in } \\
\text { the post-adoption period divided by the \# of peer firms in the same country-industry } \\
\text { using the same local accounting standard in the pre-adoption period. Industry } \\
\text { classification is based on the industry variable in Worldscope ( } 11 \text { industries). }\end{array}$ & DeFond et al. (2011) \\
\hline & $\log ($ total assets $)$ & $\log (\mathrm{TA})_{\mathrm{i}, \mathrm{t}}$ & Log of total assets (in U.S. dollars). & Datastream \\
\hline & ROA & $\mathrm{NI}_{\mathrm{i}, \mathrm{t}} / \mathrm{TA}_{\mathrm{i}, \mathrm{t}}$ & Net income before extraordinary items divided by total assets. & Datastream \\
\hline & Leverage & $\mathrm{TL}_{\mathrm{i}, \mathrm{l}} / \mathrm{TA}_{\mathrm{i}, \mathrm{t}}$ & Ending total liability divided by ending total assets. & Datastream \\
\hline & Dividend yield & $\operatorname{Div}_{\mathrm{i}, \mathrm{t}} / \mathrm{CE}_{\mathrm{i}, \mathrm{t}}$ & Dividends per share divided by the book value per share. & Datastream \\
\hline & Market-to-book & $\mathrm{MV} / \mathrm{BV}_{\mathrm{i}, \mathrm{t}}$ & Market value of equity divided by book value of equity. & Datastream \\
\hline & \# of analysts & $\mathrm{N}_{\mathrm{i}, \mathrm{t}}$ & Number of analysts following the firm at year-end. & Datastream \\
\hline & Big Five auditors & $\mathrm{I}_{\mathrm{i}, \mathrm{t}}$ & $\begin{array}{l}\text { An indicator equal that takes a value of one if the firm is audited by a Big Five audit } \\
\text { firm. We use the names of the auditors provided by Datastream and Audit Analytics } \\
\text { (for U.S. firms). }\end{array}$ & $\begin{array}{l}\text { Datastream \& Audit } \\
\text { Analytics }\end{array}$ \\
\hline & Foreign assets & $\begin{array}{l}100 *(\text { foreign } \\
\text { assets/ sales })_{\mathrm{i}, \mathrm{t}}\end{array}$ & $\begin{array}{l}\text { Percentage of foreign assets relative to total sales reported. For foreign assets, we use } \\
\text { the international assets variable in Datastream, which represents the total (or } \\
\text { identifiable) assets of all non-domestic operations. }\end{array}$ & Datastream \\
\hline & Stock returns & Return $_{\mathrm{i}, \mathrm{t}-1}$ & Prior year raw stock returns. & Datastream \\
\hline & Stock volatility & $\mathrm{Vol}_{\mathrm{i}, \mathrm{t}-1}$ & Standard deviation of monthly stock returns, measured over the previous year. & Datastream \\
\hline & Sales growth & $\% \Delta$ Sales $_{i, t-1}$ & Percentage growth in sales during the previous year. & Datastream \\
\hline
\end{tabular}


Table 1 Distribution of mutual funds by country of domicile

This table presents the asset size and investment pattern of mutual funds by the fund's country of domicile. AUM invested in foreign securities in column 2 is the aggregate fund holdings in all securities incorporated in a different country than the one where the fund is domiciled. Global AUM invested in foreign securities is the sum of all rows in column 2. Year of IFRS adoption in column 4 is from country-level mandatory IFRS adoption based on IAS plus, published by Deloitte Touche Tohmatsu, and from the country reports from the IFRS Adoption Research Group (source: http://www.adoptifrs.org). * indicates countries that chose to adopt IFRS by converging the local GAAP to a version of IFRS; for such countries, we assume the local GAAP to be a version of IFRS from one year after the convergence process.

Sources: International Thomson Financial Securities mutual fund database for holdings of non-U.S. mutual funds. For holdings of U.S. securities, we use the 13(f) filings of U.S. mutual funds provided by Thomson Financial.

\begin{tabular}{|c|c|c|c|c|}
\hline Fund country & $\begin{array}{c}\text { (1) } \\
\text { \# of funds }\end{array}$ & $\begin{array}{c}\text { (2) } \\
\text { AUM invested } \\
\text { in foreign securities } \\
\text { (in million USD) }\end{array}$ & $\begin{array}{c}\text { (3) } \\
\text { AUM invested } \\
\text { in foreign securities } \\
\text { /Global AUM invested in } \\
\text { foreign securities }\end{array}$ & $\begin{array}{c}(4) \\
\text { Year of } \\
\text { IFRS } \\
\text { adoption }\end{array}$ \\
\hline \multicolumn{5}{|c|}{ Funds from countries that require mandatory adoption of IFRS (as of end of the sample period, 2007) } \\
\hline AUSTRALIA* & 379 & 21,700 & 0.012 & 2005 \\
\hline AUSTRIA & 314 & 7,071 & 0.004 & 2005 \\
\hline BELGIUM & 694 & 23,987 & 0.014 & 2005 \\
\hline CZECH REPUBLIC & 22 & 276 & 0.000 & 2005 \\
\hline DENMARK & 382 & 15,343 & 0.009 & 2005 \\
\hline ESTONIA & 7 & 339 & 0.000 & 2005 \\
\hline FINLAND & 206 & 5,349 & 0.003 & 2005 \\
\hline FRANCE & 1,421 & 52,668 & 0.030 & 2005 \\
\hline GERMANY & 6,245 & 152,951 & 0.087 & 2005 \\
\hline GREECE & 195 & 483 & 0.000 & 2005 \\
\hline HONG KONG & 341 & 30,225 & 0.017 & 2005 \\
\hline HUNGARY & 6 & 79 & 0.000 & 2005 \\
\hline ICELAND & 5 & 95 & 0.000 & 2005 \\
\hline IRELAND & 197 & 33,499 & 0.019 & 2005 \\
\hline ITALY & 982 & 40,968 & 0.023 & 2005 \\
\hline NETHERLANDS & 365 & 43,906 & 0.025 & 2005 \\
\hline NORWAY & 256 & 67,430 & 0.038 & 2005 \\
\hline POLAND & 39 & 457 & 0.000 & 2005 \\
\hline PORTUGAL & 180 & 1,105 & 0.001 & 2005 \\
\hline SOUTH AFRICA & 249 & 2,071 & 0.001 & 2005 \\
\hline SPAIN & 4,910 & 10,861 & 0.006 & 2005 \\
\hline SWEDEN & 635 & 24,289 & 0.014 & 2005 \\
\hline SWITZERLAND & 1,234 & 58,325 & 0.033 & 2005 \\
\hline UNITED KINGDOM & 3,410 & 285,747 & 0.162 & 2005 \\
\hline \multicolumn{5}{|c|}{ Funds from countries that did not adopt IFRS (as of 2007) } \\
\hline ARGENTINA & 64 & 280 & 0.000 & 2009 \\
\hline BRAZIL & 578 & 452 & 0.000 & 2010 \\
\hline CANADA & 1,683 & 85,512 & 0.049 & 2011 \\
\hline CHILE & 115 & 460 & 0.000 & 2009 \\
\hline CHINA & 132 & 90 & 0.000 & 2009 \\
\hline INDIA & 288 & 1,467 & 0.001 & 2011 \\
\hline JAPAN & 1,089 & 12,606 & 0.007 & - \\
\hline MEXICO & 100 & 2,019 & 0.001 & - \\
\hline SINGAPORE & 345 & 27,018 & 0.015 & - \\
\hline TAIWAN & 264 & 64 & 0.000 & - \\
\hline THAILAND & 64 & 64 & 0.000 & - \\
\hline UNITED STATES & 7,818 & 749,858 & 0.426 & - \\
\hline TOTAL & 35,215 & $1,759,116$ & 1.000 & \\
\hline
\end{tabular}




\section{Table 2 Country distribution of the sample firms}

This table presents the distribution of investees in IFRS adopting vs. non-adopting countries from 2003 and 2007. Panel A presents the distribution of the sample in countries that mandated the adoption of IFRS reporting; Panel B shows the distribution of countries that either did not allow or did not require IFRS reporting during our sample period. Countrylevel mandatory IFRS adoption is based on IAS plus, published by Deloitte Touche Tohmatsu, and the country reports from the IFRS Adoption Research Group (source: http://www.adoptifrs.org). The coding of firm-level accounting standards is from the Datastream classification (WS07536). We follow the classification of Daske et al. (2008) to categorize accounting standards into IFRS and local GAAP. Median firm level investment weight in column 2 is the median investment weights from all firms from each countryfund. See section III for a detailed derivation of the investment weights. * indicates countries that chose to adopt IFRS by converging the local GAAP to a version of IFRS; for such countries, we assume the local GAAP to be a version of IFRS from one year after the convergence process.

Panel A: Distribution of firms in IFRS adopting countries

\begin{tabular}{|c|c|c|c|}
\hline Country & $\begin{array}{c}\text { (1) } \\
\text { \# of firms }\end{array}$ & $\begin{array}{l}\text { (2) } \\
\text { Median firm level } \\
\text { investment weight }\end{array}$ & $\begin{array}{c}\text { (3) } \\
\text { Year of IFRS } \\
\text { adoption }\end{array}$ \\
\hline AUSTRALIA $^{*}$ & 539 & 0.16 & 2005 \\
\hline AUSTRIA & 36 & 0.73 & 2005 \\
\hline BELGIUM & 67 & 0.31 & 2005 \\
\hline CZECH REPUBLIC & 2 & 1.01 & 2005 \\
\hline DENMARK & 90 & 0.24 & 2005 \\
\hline ESTONIA & 8 & 0.94 & 2005 \\
\hline FINLAND & 112 & 0.59 & 2005 \\
\hline FRANCE & 354 & 0.42 & 2005 \\
\hline GERMANY & 220 & 0.45 & 2005 \\
\hline GREECE & 176 & 0.13 & 2005 \\
\hline HUNGARY & 5 & 1.02 & 2005 \\
\hline IRELAND & 46 & 0.81 & 2005 \\
\hline ITALY & 74 & 0.25 & 2005 \\
\hline LUXEMBOURG & 25 & 0.59 & 2005 \\
\hline NEW ZEALAND & 27 & 0.14 & 2007 \\
\hline NORWAY & 143 & 0.43 & 2005 \\
\hline POLAND & 82 & 0.49 & 2005 \\
\hline PORTUGAL & 43 & 0.22 & 2005 \\
\hline SOUTH AFRICA & 167 & 0.12 & 2005 \\
\hline SPAIN & 126 & 0.31 & 2005 \\
\hline SWEDEN & 293 & 0.35 & 2005 \\
\hline SWITZERLAND & 61 & 0.33 & 2005 \\
\hline NETHERLANDS & 144 & 0.84 & 2005 \\
\hline U.K. & 587 & 0.36 & 2005 \\
\hline VENEZUELA & 2 & 0.17 & 2005 \\
\hline TOTAL & 3,429 & 0.33 & \\
\hline
\end{tabular}

Panel B: Distribution of firms in non-IFRS adopting countries

\begin{tabular}{|c|c|c|c|}
\hline Country & $\begin{array}{c}\text { (1) } \\
\text { \# of firms }\end{array}$ & $\begin{array}{l}\text { (2) } \\
\text { Median firm level } \\
\text { investment weight }\end{array}$ & $\begin{array}{c}(3) \\
\text { Year of IFRS } \\
\text { adoption }\end{array}$ \\
\hline ARGENTINA & 46 & 0.07 & - \\
\hline BRAZIL & 262 & 0.14 & - \\
\hline CANADA & 830 & 0.23 & 2011 \\
\hline CHILE & 104 & 0.13 & - \\
\hline CHINA & 146 & 0.21 & - \\
\hline EGYPT & 19 & 0.08 & - \\
\hline INDIA & 503 & 0.22 & - \\
\hline INDONESIA & 172 & 0.30 & - \\
\hline ISRAEL & 162 & 0.12 & 2008 \\
\hline JAPAN & 1,856 & 0.21 & - \\
\hline KOREA & 661 & 0.19 & 2011 \\
\hline MALAYSIA & 385 & 0.15 & - \\
\hline MEXICO & 122 & 0.19 & - \\
\hline PAKISTAN & 43 & 0.04 & - \\
\hline PERU & 13 & 0.08 & 2011 \\
\hline PHILIPPINES & 16 & 0.08 & - \\
\hline RUSSIA & 34 & 0.26 & - \\
\hline SINGAPORE & 311 & 0.24 & - \\
\hline THAILAND & 360 & 0.23 & - \\
\hline TURKEY & 134 & 0.36 & 2008 \\
\hline U.S. & 4,991 & 0.22 & - \\
\hline TOTAL & 11,170 & 0.21 & \\
\hline
\end{tabular}




\section{Table 3 Descriptive statistics of sample firms}

Panel A presents the firm characteristics of the mandatory and non-adopter firms. Mandatory adopters are firms incorporated in IFRS adopting countries and adopted IFRS for the first time within the two years after it was mandated. Non-adopters are firms incorporated in non-IFRS adopting countries and report using local accounting standards as of 2007. Refer to Table 2 for definitions and the country sample of IFRS adopting and non-adopting countries. Panel B presents the descriptive of the investment weight for our sample in the levels analysis. The over/underweight is a measure of the amount each firm is over or underweighted by investors in different countries relative to the global portfolio. If the measure is greater (less) than one, this indicates that a firm is over (under)weighted in the country-investor's portfolio relative to the global benchmark. See section III and Appendix A for a detailed computation of the over/underweight measure. See Appendix $\mathrm{C}$ for the definitions of all other variables.

Panel A: Firm characteristics of different types of IFRS adopters

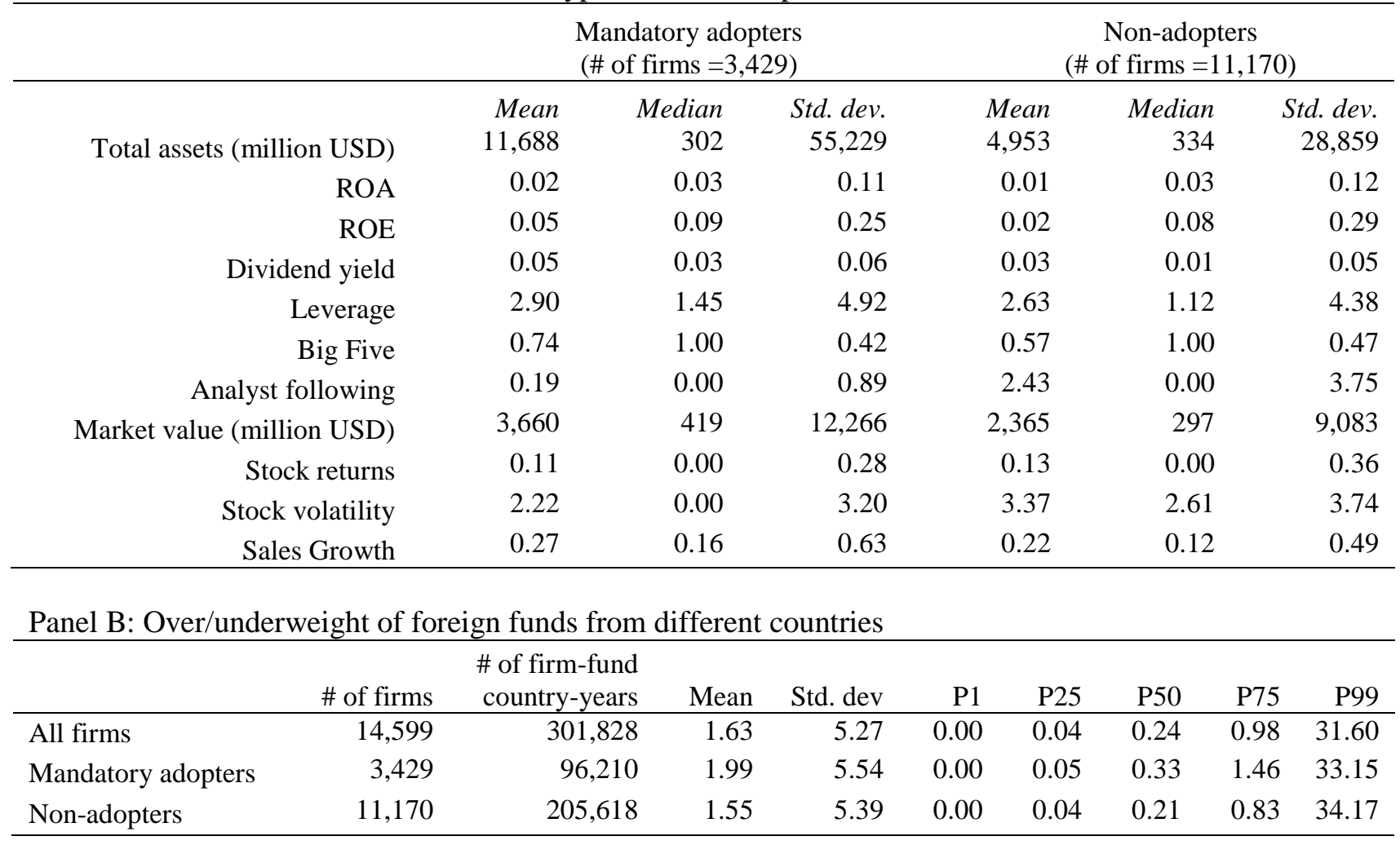




\section{Table 4 Effect of local accounting distance prior to IFRS adoption}

This table presents the estimates from an OLS regression of over/underweight on local accounting distance (LAD) for the years prior to IFRS adoption. The unit of analysis is the firm-level investment weight disaggregated by the fund's country. Over/underweight is a measure of the amount each firm is over or underweighted by investors in different countries relative to the global portfolio. If the measure is greater (less) than one, this indicates that a firm is over (under)weighted in the country-investor's portfolio relative to the global benchmark. See section III and Appendix A for a detailed computation of the over/underweight measure. LAD is a measure of the difference in the firm's and the investor's home countries' local accounting standards. See Appendix B for a detailed computation of the $L A D$ measures. In column 1, we use all mandatory adopters but limit the sample to firm-years before the firm adopted IFRS. Column 2 includes all observations for the non-adopters throughout our sample period. Refer to Appendix $\mathrm{C}$ for the definitions of all other variables. ${ }^{*}, * * * * *$ denote significance at the $10 \%, 5 \%$, and $1 \%$ levels, respectively, based on two-sided tests. ${ }^{\text {a }}$ denotes variables where the underlying data is multiplied by 1,000 for ease of exposition.

\begin{tabular}{|c|c|c|c|c|}
\hline \multirow[b]{5}{*}{ Variables } & \multicolumn{4}{|c|}{ Dependent variable: Investment weight of foreign funds from different countries } \\
\hline & \multirow{3}{*}{\multicolumn{2}{|c|}{$\begin{array}{c}(1) \\
\text { Mandatory adopters } \\
\text { (Pre-firm adoption) }\end{array}$}} & \multirow{2}{*}{\multicolumn{2}{|c|}{$\begin{array}{c}(2) \\
\text { Non-adopters }\end{array}$}} \\
\hline & & & & \\
\hline & & & & \\
\hline & Coeff. & $(t$-stat $)$ & Coeff. & $(t$-stat $)$ \\
\hline $\mathrm{LAD}_{\mathrm{i} . \mathrm{h}}$ & $-0.088 * *$ & $(-1.969)$ & $-0.064^{*}$ & $(-1.650)$ \\
\hline \multicolumn{5}{|l|}{ Firm-level controls } \\
\hline Log (Total assets) & -0.065 & $(-1.535)$ & -0.065 & $(-1.535)$ \\
\hline ROA & 0.058 & $(0.091)$ & 0.058 & $(0.091)$ \\
\hline Leverage & 0.013 & $(1.436)$ & 0.013 & $(1.436)$ \\
\hline Market-to-book & -0.030 & $(-1.544)$ & -0.030 & $(-1.544)$ \\
\hline Dividend yield & -0.365 & $(-0.721)$ & -0.365 & $(-0.721)$ \\
\hline \# of analysts & 0.004 & $(0.178)$ & 0.004 & $(0.178)$ \\
\hline Big Five auditor & 0.119 & $(1.306)$ & 0.119 & $(1.306)$ \\
\hline Foreign assets & 0.001 & $(0.381)$ & 0.001 & $(0.381)$ \\
\hline Stock returns ${ }^{\mathbf{a}}$ & 0.003 & $(1.483)$ & 0.003 & $(1.483)$ \\
\hline Stock volatility $^{\mathbf{a}}$ & $-0.001^{* * *}$ & $(-3.998)$ & $-0.001^{* * *}$ & $(-3.998)$ \\
\hline Sales growth ${ }^{\mathbf{a}}$ & 0.392 & $(1.182)$ & 0.392 & $(1.182)$ \\
\hline Comparability $^{\mathbf{a}}$ & -0.065 & $(-1.535)$ & 0.099 & $(0.334)$ \\
\hline \multicolumn{5}{|l|}{ Country-level controls } \\
\hline \# of listed companies & 0.099 & $(0.334)$ & 0.001 & $(0.537)$ \\
\hline FDI flows & 0.001 & $(0.537)$ & 0.022 & $(0.910)$ \\
\hline Index returns & 0.022 & $(0.910)$ & -0.001 & $(-0.245)$ \\
\hline GDP growth $(\%)$ & -0.001 & $(-0.245)$ & 0.019 & $(0.222)$ \\
\hline GDP per capita (USD) $^{\mathbf{a}}$ & 0.019 & $(0.222)$ & $-0.128^{* *}$ & $(-2.097)$ \\
\hline Stock market turnover & $-0.128^{* *}$ & $(-2.097)$ & 0.004 & $(0.704)$ \\
\hline Real exchange rate & 0.004 & $(0.704)$ & -0.030 & $(-1.587)$ \\
\hline Annual inflation & -0.030 & $(-1.587)$ & $-0.069^{*}$ & $(-1.802)$ \\
\hline \multicolumn{5}{|l|}{ Country-pair controls } \\
\hline Geographic distance & $2.340^{* * *}$ & $(4.691)$ & $-2.340^{* * *}$ & $(-4.691)$ \\
\hline Language distance & 0.210 & $(0.804)$ & 0.210 & $(0.804)$ \\
\hline Net trade (USD) ${ }^{\mathbf{a}}$ & 0.001 & $(0.207)$ & 0.001 & $(0.207)$ \\
\hline Constant & $7.724 * * *$ & $(2.697)$ & $7.724^{* * *}$ & $(2.697)$ \\
\hline SE cluster by country & \multicolumn{2}{|c|}{ Yes } & \multicolumn{2}{|c|}{ Yes } \\
\hline Country FE & \multicolumn{2}{|c|}{ Yes } & \multicolumn{2}{|c|}{ Yes } \\
\hline Industry-year FE & \multicolumn{2}{|c|}{ Yes } & \multicolumn{2}{|c|}{ Yes } \\
\hline$\#$ of obs & \multicolumn{2}{|c|}{41,427} & \multicolumn{2}{|c|}{205,618} \\
\hline Adjusted R-sqr. & \multicolumn{2}{|c|}{0.051} & \multicolumn{2}{|c|}{0.053} \\
\hline
\end{tabular}




\section{Table 5 Effect of changes in accounting distance from the investee's IFRS adoption: Mandatory IFRS adoption of the firm}

This table presents the estimates from an OLS regression of the change in investment weights on the change in accounting distance triggered by a firm's IFRS adoption $\left(\triangle A D \_F I R M_{\mathrm{i}, \mathrm{h}}\right)$. The unit of analysis is the firm-level investment weights disaggregated by the fund's country. The dependent variable is the change in the average investment weights of a firm i held by country investor h two years before and after IFRS adoption. See Appendix A for a detailed computation of the investment weight measure. $\triangle A D_{-} F I R M_{i, h}$ is the changes in accounting distance between firm $\mathrm{i}$ and country-investor $\mathrm{h}$ following the mandatory IFRS adoption of firm $\mathrm{i}$. $\triangle A D_{-} F I R M_{\mathrm{i} . \mathrm{h}}$ takes a lower value if there is a greater reduction in accounting distance. See Appendix $\mathrm{B}$ for a detailed computation of the $\triangle A D_{-} F I R M_{\mathrm{i}, \mathrm{h}}$ measure. In column 1, we use all adoption events as the event that triggers the changes in accounting distance. In column 2 , we use only adoption events that decreased AD, that is, $\triangle A D_{-} F I R M_{\text {i.h }}<0$. All control variables are specified as changes in the average values two years before and after the adoption event. See Appendix $\mathrm{C}$ for the definitions of all other variables. ${ }^{* * * * * *}$ denote significance at the $10 \%, 5 \%$, and $1 \%$ levels, respectively, based on two-sided tests. ${ }^{\text {a }}$ denotes variables where the underlying data is multiplied by 1,000 for ease of exposition.

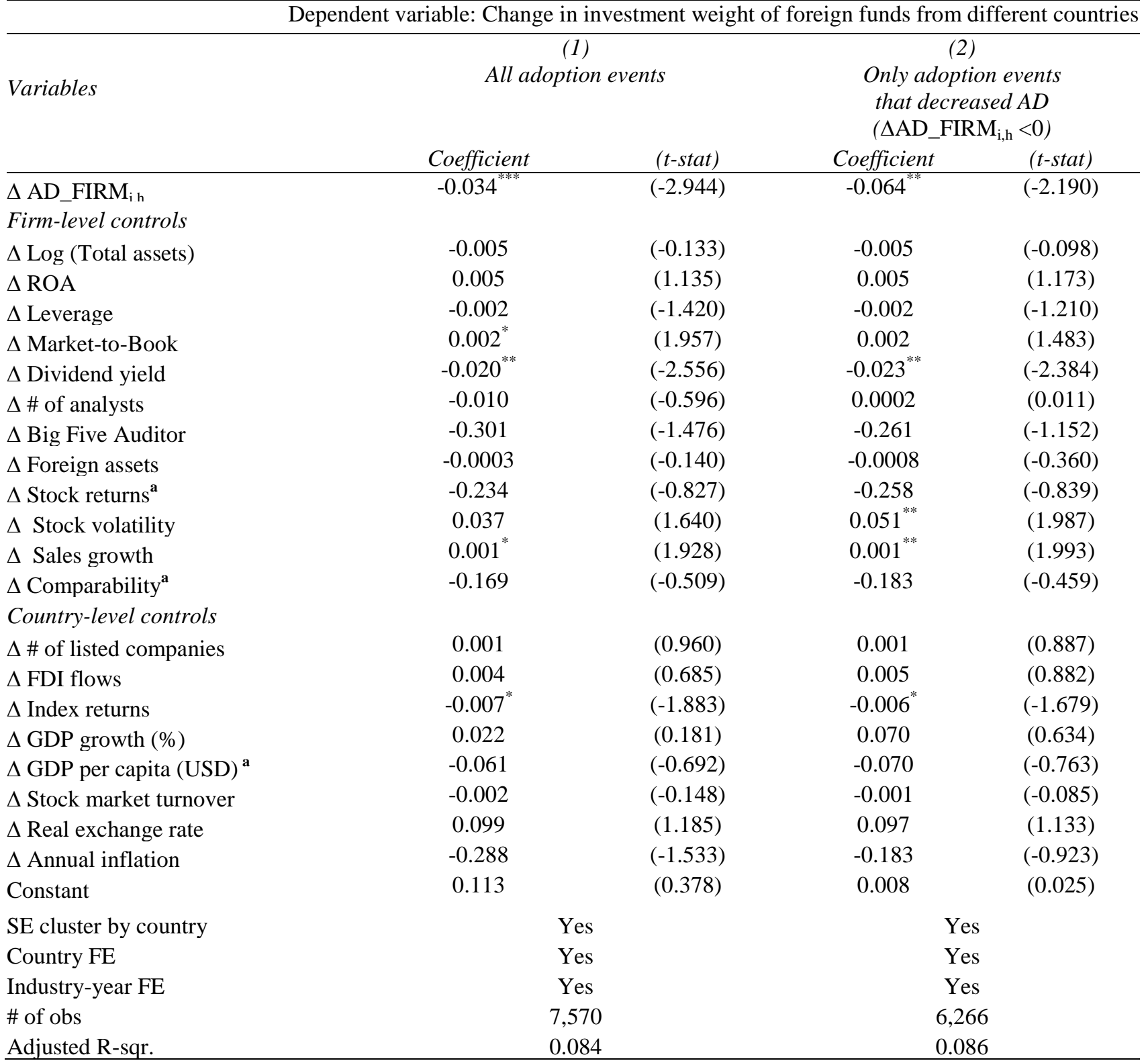




\section{Table 6 Effect of changes in accounting distance from the investor's IFRS adoption: Mandatory IFRS adoption in the fund's country}

This table presents the estimates from an OLS regression of the change in investment weights on the change in accounting distance triggered by IFRS adoption in the fund's country $\mathrm{h}\left(\triangle A D_{-} F U N D_{\mathrm{i} . \mathrm{h}}\right)$. The unit of analysis is the firm-level investment weight disaggregated by the fund's country (i.e., firm-fund country). The dependent variable is the change in the average investment weights of a firm i held by country investor h two years before and after IFRS adoption. See Appendix A for a detailed computation of the investment weight measure. $\triangle A D_{-} F U N D_{\mathrm{i} . \mathrm{h}}$ is the change in accounting distance from IFRS adoption in country $\mathrm{h}$ where fund is incorporated. $\triangle A D_{-} F U N D_{\mathrm{i} . \mathrm{h}}$ takes a lower value if there is a greater reduction in accounting. See Appendix B for a detailed computation of the $\triangle A D_{-} F U N D_{\mathrm{i}, \mathrm{h}}$ measure. In column 1, we use all adoption events as the event that triggers changes in accounting distance. In column 2, we use only adoption events that decreased $\mathrm{AD}$, that is, $\triangle A D_{-} F U N D_{\mathrm{i} . \mathrm{h}}<0$. All control variables are specified as changes in the average values two years before and after the adoption event. See Appendix $\mathrm{C}$ for the definitions of all other variables. ${ }^{* * * * * *}$ denote significance at the $10 \%, 5 \%$, and $1 \%$ levels, respectively, based on two-sided tests. ${ }^{\text {a }}$ denotes variables where the underlying data is multiplied by 1,000 for ease of exposition.

Dependent variable: Change in investment weight of foreign funds from different countries

\begin{tabular}{|c|c|c|c|c|}
\hline \multirow{2}{*}{$\begin{array}{l}\text { Variables } \\
\triangle \mathrm{AD}_{\text {_FUND }} \mathrm{i.h}\end{array}$} & \multicolumn{2}{|c|}{$\begin{array}{c}\text { (1) } \\
\text { All adoption events }\end{array}$} & \multicolumn{2}{|c|}{$\begin{array}{c}(2) \\
\text { Only adoptions events } \\
\text { that decreased } A D \\
\left(\triangle \mathrm{AD} \_\mathrm{FUND}_{\mathrm{i}, \mathrm{h}}<0\right)\end{array}$} \\
\hline & -0.005 & $(-0.396)$ & $-0.038^{* * *}$ & $(-2.893)$ \\
\hline \multicolumn{5}{|l|}{ Firm-level controls } \\
\hline$\Delta \log$ (Total assets) & $-0.485^{* * *}$ & $(-11.989)$ & $-0.467^{* * *}$ & $(-8.136)$ \\
\hline$\Delta \mathrm{ROA}$ & $0.013^{* *}$ & $(2.294)$ & $0.524^{* * *}$ & $(5.795)$ \\
\hline$\Delta$ Leverage & $-0.001^{*}$ & $(-1.842)$ & $-0.002^{* *}$ & $(-2.447)$ \\
\hline$\Delta$ Market-to-Book & $0.397^{* * *}$ & $(2.883)$ & 0.066 & $(0.284)$ \\
\hline$\Delta$ Dividend yield & $-0.084^{* *}$ & $(-2.236)$ & -0.022 & $(-0.831)$ \\
\hline$\Delta \#$ of analysts & $0.015^{* * *}$ & $(3.189)$ & $0.016^{* * * *}$ & (3.144) \\
\hline$\Delta$ Big Five Auditor & -0.088 & $(-0.617)$ & -0.150 & $(-0.805)$ \\
\hline$\Delta$ Foreign assets ${ }^{\mathrm{a}}$ & 0.150 & $(0.590)$ & 0.0036 & $(0.010)$ \\
\hline$\Delta$ Stock returns ${ }^{\mathbf{a}}$ & -0.438 & $(-0.943)$ & -0.067 & $(-0.118)$ \\
\hline$\Delta$ Stock volatility ${ }^{\mathbf{a}}$ & -0.006 & $(-1.057)$ & -0.014 & $(-1.006)$ \\
\hline$\Delta$ Sales growth ${ }^{\mathrm{a}}$ & 0.076 & $(0.706)$ & 0.135 & $(0.988)$ \\
\hline$\Delta$ Comparability & 0.326 & (1.026) & -0.012 & $(-0.049)$ \\
\hline \multicolumn{5}{|l|}{ Country-level controls } \\
\hline$\Delta \#$ of listed companies & -0.001 & $(-0.539)$ & 0.001 & $(0.875)$ \\
\hline$\Delta$ FDI flows & 0.103 & $(0.616)$ & 0.013 & $(0.076)$ \\
\hline$\Delta$ Index returns & $-0.026^{* *}$ & $(-2.533)$ & $-0.023^{* *}$ & $(-2.160)$ \\
\hline$\Delta$ GDP growth $(\%)$ & -0.064 & $(-0.291)$ & -0.041 & $(-0.186)$ \\
\hline$\Delta$ GDP per capita (USD) ${ }^{\mathbf{a}}$ & 0.052 & $(0.466)$ & 0.131 & $(1.573)$ \\
\hline$\Delta$ Stock market turnover & 0.002 & $(0.145)$ & -0.005 & $(-0.523)$ \\
\hline$\Delta$ Real exchange rate & 0.076 & $(1.316)$ & 0.065 & $(1.615)$ \\
\hline$\Delta$ Annual inflation & 0.012 & $(0.126)$ & 0.106 & $(0.781)$ \\
\hline Constant & $1.031^{*}$ & $(1.664)$ & -0.247 & $(-0.330)$ \\
\hline SE cluster by country & \multicolumn{2}{|c|}{ Yes } & \multicolumn{2}{|c|}{ Yes } \\
\hline Country fixed effects & \multicolumn{2}{|c|}{ Yes } & \multicolumn{2}{|c|}{ Yes } \\
\hline Industry-year fixed effects & \multicolumn{2}{|c|}{ Yes } & \multicolumn{2}{|c|}{ Yes } \\
\hline$\#$ of obs & \multicolumn{2}{|c|}{56,062} & \multicolumn{2}{|c|}{41,109} \\
\hline Adjusted R-sqr. & \multicolumn{2}{|c|}{0.123} & \multicolumn{2}{|c|}{0.120} \\
\hline
\end{tabular}




\section{Table 7 Additional analysis}

This table presents the estimates from an OLS regression of the change in investment weights on the change in accounting distance triggered by a firm's IFRS adoption $\left(\triangle A D_{-} F I R M_{\mathrm{i} . \mathrm{h}}\right)$. The unit of analysis is the firm-level investment weights disaggregated by the fund's country (i.e., firm-fund country). The dependent variable is the change in the average investment weights of a firm i held by country investor $\mathrm{h}$ two years before and after IFRS adoption. See Appendix A for a detailed computation of the investment weight measure. $\triangle A D_{-} F I R M_{\text {i.h }}$ is the change in accounting distance from IFRS adoption of firm i. $\triangle A D_{-} F I R M_{\text {i.h }}$ takes a lower value if there is a greater reduction in accounting distance. See Appendix B for a detailed computation of the $\triangle A D \_F I R M$ i.h measure. Column 1 compares the coefficient estimates after partitioning the sample into high and low enforcement countries. For the enforcement measures, we use (i) the rule of law index (Kaufman et al. 2003) in column 1 and (ii) the earnings management index from Leuz et al. (2003) in column 2 to partition the sample into firms in high and low enforcement countries. We use the country sample-median to classify the firms' country into high and low enforcement countries. All controls are specified as changes in the average values two years before and after IFRS adoption. Refer to Appendix $\mathrm{C}$ for the definitions of all other variables. ${ }^{* * * * * *}$ denote significance at the $10 \%, 5 \%$, and $1 \%$ levels, respectively, based on two-sided tests. ${ }^{a}$ denotes variables where the underlying data is multiplied by 1,000 for ease of exposition.

\begin{tabular}{|c|c|c|c|c|}
\hline \multirow[t]{2}{*}{ Enforcement measures: } & \multicolumn{2}{|c|}{$\begin{array}{c}\text { (1) } \\
\text { Rule of law }\end{array}$} & \multicolumn{2}{|c|}{$\begin{array}{c}\text { (2) } \\
\text { Accounting enforcement }\end{array}$} \\
\hline & High & Low & High & Low \\
\hline$\Delta \mathrm{AD}_{-} \mathrm{FIRM}_{\mathrm{i} . \mathrm{h}}$ & $\begin{array}{l}-0.089^{* *} \\
(-2.093)\end{array}$ & $\begin{array}{c}-0.043 \\
(-1.264)\end{array}$ & $\begin{array}{l}-0.133^{*} \\
(-1.686)\end{array}$ & $\begin{array}{l}-0.046 \\
(-1.635)\end{array}$ \\
\hline \multicolumn{5}{|l|}{ Firm-level controls } \\
\hline$\Delta \log$ (Total assets) & $\begin{array}{c}0.028 \\
(0.706)\end{array}$ & $\begin{array}{c}-0.034 \\
(-0.349)\end{array}$ & $\begin{array}{c}-0.009 \\
(-0.104)\end{array}$ & $\begin{array}{l}-0.001 \\
(-0.035)\end{array}$ \\
\hline$\triangle \mathrm{ROA}$ & $\begin{array}{c}0.005 \\
(1.192)\end{array}$ & $\begin{array}{c}0.038 \\
(0.207)\end{array}$ & $\begin{array}{l}0.002^{*} \\
(1.959)\end{array}$ & $\begin{array}{c}0.015 \\
(1.468)\end{array}$ \\
\hline$\Delta$ Leverage & $\begin{array}{l}-0.0002 \\
(-0.136)\end{array}$ & $\begin{array}{l}-0.0095 \\
(-1.368)\end{array}$ & $\begin{array}{l}-0.0097 \\
(-1.195)\end{array}$ & $\begin{array}{l}0.0001 \\
(0.157)\end{array}$ \\
\hline$\Delta$ Market-to-Book & $\begin{array}{l}0.0002 \\
(0.041)\end{array}$ & $\begin{array}{c}0.005 \\
(1.391)\end{array}$ & $\begin{array}{c}0.005 \\
(1.299)\end{array}$ & $\begin{array}{l}-0.001 \\
(-0.432)\end{array}$ \\
\hline$\Delta$ Dividend yield & $\begin{array}{l}-0.804 \\
(-1.051)\end{array}$ & $\begin{array}{c}0.009 \\
(0.467)\end{array}$ & $\begin{array}{c}0.005 \\
(0.194)\end{array}$ & $\begin{array}{l}0.205^{*} \\
(1.688)\end{array}$ \\
\hline$\Delta \#$ of analysts & $\begin{array}{c}0.027 \\
(0.953)\end{array}$ & $\begin{array}{l}-0.030 \\
(-1.288)\end{array}$ & $\begin{array}{l}-0.012 \\
(-0.566)\end{array}$ & $\begin{array}{c}0.045 \\
(1.034)\end{array}$ \\
\hline$\Delta$ Big Five auditor & $\begin{array}{l}-0.132 \\
(-0.516)\end{array}$ & $\begin{array}{l}-0.637 \\
(-1.248)\end{array}$ & $\begin{array}{l}-0.806 \\
(-1.453)\end{array}$ & $\begin{array}{c}0.109 \\
(0.613)\end{array}$ \\
\hline$\Delta$ Foreign assets & $\begin{array}{l}-0.001 \\
(-0.580)\end{array}$ & $\begin{array}{l}0.0008 \\
(0.140)\end{array}$ & $\begin{array}{l}0.0011 \\
(0.370)\end{array}$ & $\begin{array}{l}-0.0050 \\
(-0.590)\end{array}$ \\
\hline$\Delta$ Comparability & $\begin{array}{l}0.391^{\mathrm{a}} \\
(0.90)\end{array}$ & $\begin{array}{l}-0.001 \\
(-1.411)\end{array}$ & $\begin{array}{l}-0.001 \\
(-1.240)\end{array}$ & $\begin{array}{l}0.451^{\mathrm{a}} \\
(1.599)\end{array}$ \\
\hline Constant & $\begin{array}{l}-0.610 \\
(-1.470)\end{array}$ & $\begin{array}{l}-0.610 \\
(-1.470)\end{array}$ & $\begin{array}{l}-0.203 \\
(-0.416)\end{array}$ & $\begin{array}{l}-0.203 \\
(-0.416)\end{array}$ \\
\hline $\begin{array}{c}\text { F-tests: Diff. between high \& low } \\
\text { [P-value] }\end{array}$ & p-val & 0.397 & $\mathrm{p}$-valu & 0.310 \\
\hline Country-level controls & & & & \\
\hline SE cluster by country-pairs & & & & \\
\hline Country fixed effects & & & & \\
\hline Industry-year fixed effects & & & & \\
\hline \# of obs & & & & \\
\hline Adjusted R-sqr. & & & & \\
\hline
\end{tabular}




\section{Table 8 Sensitivity analysis}

This table presents the estimates from an OLS regression of the change in investment weights on the change in accounting distance triggered by a firm's IFRS adoption $\left(\triangle A D_{-} F I R M_{\mathrm{i} . \mathrm{h}}\right)$. The unit of analysis is the firm-level investment weights disaggregated by the fund's country (i.e., firm-fund country). The dependent variable is the change in the average investment weights of a firm $i$ held by country investor h two years before and after IFRS adoption. See Appendix A for a detailed computation of the investment weight measure. $\triangle A D_{-} F I R M_{\mathrm{i} . \mathrm{h}}$ is the change in accounting distance from IFRS adoption of firm i. $\triangle A D_{-} F I R M_{\mathrm{i} . \mathrm{h}}$ takes a lower value if there is a greater reduction in accounting distance. See Appendix B for a detailed computation of the $\triangle A D \_F I R M_{\mathrm{i}}$ measure. All controls are specified as changes in the average values two years before and after IFRS adoption. In column 1, we limit the sample only to adoption events that lead to a small residual $\mathrm{AD}$, that is, $A D_{-} F I R M_{\text {i.h }}<$ sample median 5 . In column 2, we repeat the analysis using an alternative measure of $\mathrm{AD}$. In column 3 , we exclude the country with the most \# of firms, and in column 4 , we exclude the country with the most \# of funds. In column 5, we use an alternative dependent variable, the \% ownership, measured as the percentage of firm i's shares held by funds in country h. For this estimation, we exclude country-funds with annual changes in AUM greater or less than 50\% relative to the global market portfolio to control for portfolio rebalancing effect. Refer to Appendix $\mathrm{C}$ for the definitions of all other variables. ${ }^{* * *},{ }^{*}{ }^{*}$ denote significance at the $10 \%, 5 \%$, and $1 \%$ levels, respectively, based on two-sided tests. ${ }^{\text {a }}$ denotes variables where the underlying data is multiplied by 1,000 for ease of exposition.

Dependent Variable: Change in investment weight of foreign funds from different countries

$\begin{array}{ccc}(1) & (2) & (3) \\ \text { Changes that } & \text { Bae et } & \text { Excluding } \\ \text { resulted in } & \text { al.'s } A D & \text { U.K. firms } \\ \text { small } A D(<5) & \text { measure } & \end{array}$

\begin{tabular}{|c|c|c|c|c|c|}
\hline \multicolumn{2}{|l|}{ Variables } & & & \multicolumn{2}{|c|}{ change in AUM) } \\
\hline$\Delta \mathrm{AD}_{-} \mathrm{FIRM}_{\mathrm{i} . \mathrm{h}}$ & $\begin{array}{l}-0.395^{\text {*** }} \\
(-4.040)\end{array}$ & $\begin{array}{l}-0.064^{* * *} \\
(-3.660)\end{array}$ & $\begin{array}{l}-0.031^{\text {**** }} \\
(-2.787)\end{array}$ & $\begin{array}{l}-0.053^{\text {***** }} \\
(-3.815)\end{array}$ & $\begin{array}{l}-0.001^{*} \\
(-1.914)\end{array}$ \\
\hline \multicolumn{6}{|l|}{ Firm-level controls } \\
\hline \multirow[t]{2}{*}{$\Delta \log ($ Total assets) } & -0.055 & -0.005 & -0.028 & -0.002 & $-0.001^{* *}$ \\
\hline & $(-0.692)$ & $(-0.142)$ & $(-0.603)$ & $(-0.043)$ & $(-2.810)$ \\
\hline \multirow[t]{2}{*}{$\Delta \mathrm{ROA}$} & 0.001 & 0.005 & 0.005 & $0.028^{* * *}$ & $0.002^{\mathrm{a}}$ \\
\hline & $(0.933)$ & $(1.137)$ & $(1.118)$ & $(18.125)$ & $(0.816)$ \\
\hline \multirow[t]{2}{*}{$\Delta$ Leverage } & -0.004 & -0.002 & -0.0004 & -0.003 & $-0.012^{\mathbf{a}^{*}}$ \\
\hline & $(-1.520)$ & $(-1.398)$ & $(-0.332)$ & $(-0.666)$ & $(-1.940)$ \\
\hline \multirow[t]{2}{*}{$\Delta$ Market-to-Book } & 0.008 & $0.002^{*}$ & 0.0001 & 0.002 & $0.029^{\mathrm{a}^{* *}}$ \\
\hline & $(1.538)$ & $(1.936)$ & $(0.033)$ & $(0.835)$ & $(2.332)$ \\
\hline \multirow[t]{2}{*}{$\Delta$ Dividend yield } & $-0.258^{* *}$ & $-0.020^{* *}$ & -0.143 & -0.025 & $-0.240^{\mathbf{a}^{\text {**** }}}$ \\
\hline & $(-2.485)$ & $(-2.590)$ & $(-0.541)$ & $(-1.337)$ & $(-2.690)$ \\
\hline \multirow[t]{2}{*}{$\Delta \#$ of analysts } & 0.011 & -0.012 & 0.015 & $-0.052^{* * *}$ & $0.002^{* * *}$ \\
\hline & $(0.268)$ & $(-0.702)$ & $(0.717)$ & $(-2.971)$ & $(3.378)$ \\
\hline \multirow[t]{2}{*}{$\Delta$ Big Five Auditor } & -0.135 & -0.310 & -0.278 & -0.699 & -0.001 \\
\hline & $(-0.599)$ & $(-1.513)$ & $(-1.241)$ & $(-1.492)$ & $(-0.615)$ \\
\hline \multirow[t]{2}{*}{$\Delta$ Foreign assets } & -0.002 & -0.0003 & -0.0002 & -0.0009 & $-0.003^{\mathbf{a}}$ \\
\hline & $(-0.260)$ & $(-0.140)$ & $(-0.010)$ & $(-0.250)$ & $(-0.180)$ \\
\hline \multirow[t]{2}{*}{$\Delta$ Stock returns ${ }^{a}$} & 0.104 & -0.219 & -0.111 & -0.001 & 0.002 \\
\hline & $(0.368)$ & $(-0.760)$ & $(-0.306)$ & $(-0.830)$ & $(0.670)$ \\
\hline \multirow[t]{2}{*}{$\Delta$ Stock volatility } & 0.031 & 0.036 & 0.028 & $0.091^{*}$ & $0.068^{\mathrm{a}}$ \\
\hline & $(1.535)$ & $(1.632)$ & $(1.267)$ & $(1.779)$ & $(0.711)$ \\
\hline \multirow[t]{2}{*}{$\Delta$ Sales growth } & 0.001 & $0.001^{* *}$ & $0.001^{*}$ & $0.003^{* *}$ & $0.004^{a}$ \\
\hline & $(1.152)$ & $(1.980)$ & $(1.803)$ & $(2.484)$ & $(1.281)$ \\
\hline \multirow[t]{2}{*}{$\Delta$ Comparability $^{a}$} & -0.283 & -0.160 & -0.193 & -0.356 & 0.004 \\
\hline & $(-0.458)$ & $(-0.494)$ & $(-0.532)$ & $(-0.618)$ & $(1.378)$ \\
\hline Country-level controls & Yes & Yes & Yes & Yes & Yes \\
\hline SE cluster by country-pairs & Yes & Yes & Yes & Yes & Yes \\
\hline Country fixed effects & Yes & Yes & Yes & Yes & Yes \\
\hline Industry-year fixed effects & Yes & Yes & Yes & Yes & Yes \\
\hline \# of obs & 3,983 & 7,880 & 6,067 & 4,130 & 7,177 \\
\hline Adjusted R-sqr. & 0.119 & 0.087 & 0.091 & 0.137 & 0.097 \\
\hline
\end{tabular}

